\title{
The glacial landsystem of a tropical glacier: Charquini Sur, Bolivian Andes
}

\author{
Jakub Małecki ${ }^{1}$, Harold Lovell ${ }^{2}$, Wojciech Ewertowski ${ }^{1}$, Łukasz Górski ${ }^{1}$, Tomasz Kurczaba ${ }^{1}$, Beata Latos ${ }^{1}$, Michał \\ Miara ${ }^{1}$, Dorota Piniarska ${ }^{1}$, Jacek Płocieniczak ${ }^{1}$, Tomasz Sowada ${ }^{1}$, Marcin Spiralski ${ }^{1}$, Anna Warczachowska ${ }^{1}$, \\ Antoine Rabatel ${ }^{3}$ \\ ${ }^{1}$ Faculty of Geographical and Geological Sciences, Adam Mickiewicz University, Poznań, Poland, \\ malecki.jk@gmail.com
}

${ }^{2}$ Department of Geography, University of Portsmouth, Portsmouth, United Kingdom, harold.lovell@port.ac.uk

${ }^{3}$ Univ. Grenoble Alpes, CNRS, IRD, Grenoble INP, IGE (UMR 5001), F-38000 Grenoble, France, antoine.rabatel@univ-grenoble-alpes.fr

\begin{abstract}
The geomorphological signature of tropical glaciers has the potential to provide important information on the response of ice masses in high-mountain environments to climate warming. This study investigates the glacial geomorphology of Charquini Sur, Bolivia. Detailed geomorphological mapping was conducted both in the field and from satellite imagery in order to produce a 1:4,000 scale geomorphological map of the glacier foreland. Sedimentological analyses (description of physical characteristics, clast shape and roundness, particle-size distribution) provided additional insight into the landform-sediment assemblage. Glacial landforms are well preserved and include up to 11 moraine ridge suites, seven of which are cross-valley frontal moraine arcs. These can be linked to an existing lichenometric chronology from previous work and record glacier recession since the local Little Ice Age (LIA) maximum in the late1600s. Lateral moraine ridges also record continuous thinning of the glacier over this time period. Smaller groups of parallel ridges are interpreted as annual moraines formed during recession. Intermorainic areas consist of flutings and a typically thin sediment cover of subglacial, supraglacial and glaciofluvial origin, with prominent ice-moulded bedrock protuberances in places. Analysis of the landform-sediment assemblage provides an insight into the main controls on landform genesis in the basin and implies there have been temporal changes in ice-marginal dynamics since the LIA. We present the first landsystem model for a tropical cirque glacier, documenting its behaviour since the LIA and providing an indication of glacier response in rapidly-warming high-mountain environments.
\end{abstract}

Keywords: cirque glacier, glacial geomorphology, glacial landsystem, moraines, high-mountain environments

\section{Introduction}

High-mountain environments are known to be warming rapidly (cf. Pepin et al., 2015) and glaciers in these regions are especially vulnerable to this change in climatic conditions (e.g. Ramírez et al., 2001; Thompson et al., 2009; Bolch et al., 2012). These glaciers are vital water resources to approximately one billion people globally (e.g. Bradley et al., 2006; Bolch et al., 2012; Pritchard, 2017), so understanding their behaviour over extended timescales is essential in order to fully comprehend the consequences of glacier recession on these communities. One such high-mountain region where glaciers are especially vulnerable to climate change is in the tropical Andes of South America (e.g. Ramírez et al., 2001), and in particular Peru and Bolivia, which contain the vast majority of the global population of tropical glaciers (2140 km² out of $2346 \mathrm{~km}^{2}$; Arendt et al., 2015). Glaciers in the Peruvian and Bolivian Andes have, in general, experienced frontal retreat interrupted by several minor re-advances following the local Little Ice Age (LIA) maximum in the $17^{\text {th }}$ century (Rabatel et al., 2008; Jomelli et al., 2009).

Documenting glacier vulnerability to climate change relies on being able to record patterns of glacier recession over an extended timescale. Globally, investigations of the response of mountain glaciers to climate change over approximately the last century has typically relied on direct measurements (e.g. mass balance stake networks), supported by remote sensing since the 1980s (e.g. Zemp et al., 2015; IPCC, 2014). Understanding historic glacier behaviour prior to these observational records (i.e. during the LIA) typically requires the investigation of often sparse datasets (if available at all) of historical mapping, photographs or written accounts (e.g. Tennant et al., 2012; Lea et al., 2014; Hannesdóttir et al., 2015; Brynjólfsson et al., 2015) and the detailed mapping and analysis of landformsediment assemblages exposed during glacier recession (e.g. Price 1969; Krüger 1994; Evans and Twigg 2002; Deline and Orombelli, 2005; Glasser et al., 2005; Evans et al., 2016a). The latter often focuses on the mapping of moraines as indicators of former glacier frontal positions, which, when combined with absolute or relative dating techniques, can help to produce detailed glacier chronologies stretching back to the onset of the Neoglacial period and beyond (e.g. Bickerton and Matthews, 1993; Bradwell et al., 2006; Davis et al., 2009; Solomina et al., 2015). 
In addition to providing important information on modern glacier terminus fluctuations over extended timescales (and in particular recession patterns), analysis of landform-sediment assemblages can also provide an insight into styles of glaciation and glaciological processes (e.g. the nature of ice-marginal and subglacial environments, glacier thermal regimes, sediment transport pathways in the glacier system). This approach focuses on identifying suites of features within a glacier foreland that together are indicative or diagnostic of a certain type of glacier behaviour (e.g. surging), known as glacial landsystems (cf. Evans, 2003a; Ingólfsson et al., 2016). The landsystem approach has been used to characterise landform-sediment assemblages in a wide range of glacial environments, both at the margins of modern glaciers and ice sheets (e.g. Evans and Rea, 1999; Evans, 2003b; Glasser and Hambrey, 2003; Kjær et al., 2008; Graham et al., 2009; Brynjólfsson et al., 2014; Schomacker et al., 2014; Ewertowski et al., 2016) and in the palaeoglacial record (e.g. Evans et al., 1999; Stokes and Clark, 1999; Golledge 2007; Darvill et al., 2017; Bickerdike et al., 2017). This ongoing work has revealed that, due to the influence of different climatic, topographic and geological settings, no universal landform pattern exists for glacial environments, and different glacier subtypes often exhibit their own typical geomorphological and sedimentological footprint (Evans, 2003a; Benn et al., 2003; Hambrey and Glasser, 2012; Ingólfsson et al., 2016).

Glaciers occur in mountain regions at all latitudes from the equator to the poles, and this means that their landsystems display a considerable amount of variability (Benn et al., 2003). Examples of the range of landform-sediment assemblages have been provided for a number of modern and palaeo glacial environments, including in low-latitude (e.g. Benn and Owen, 2002; Owen et al., 2003), mid-latitude (e.g. Benn, 1989; Kirkbride, 2000; Glasser and Hambrey, 2002; Deline and Orombelli, 2005; Robersen, 2008; Burki et al., 2009; Lukas, 2012; Bendle and Glasser, 2012; Chandler and Lukas, 2017), and high-latitude (e.g. Fitzsimons, 2003; Glasser and Hambrey, 2003; Lukas et al., 2005; Evans et al., 2006a, 2016b; Evans, 2010; Brynjólfsson et al., 2012) settings. To our knowledge, tropical glaciers are yet to be the subject of detailed geomorphological investigation. Characterising the glacial landsystem produced by modern tropical glaciers will thus help to broaden the range of glacial landsystems. Detailed gemorphological mapping of forelands exposed by receding tropical glaciers will also provide a longer-term context for their present-day behaviour, contributing to the understanding of the full range of glacier response to climate change in different glacial environments across the globe.

The exceptionally well preserved post-LIA glacial landforms of the Charquini Sur glacier, Bolivia, combined with its established recessional history (Rabatel et al., 2005, 2006, 2008), provide an excellent opportunity to study its landform-sediment assemblages and associated glacial processes. To date, studies in this region have primarily focused on mapping and dating of Pleistocene and Holocene moraine limits (e.g. Glasser et al., 2009; Smith et al., 2009; Jomelli et al., 2011; Heine, 2011), mapping of volcanic and glacial hazards (e.g. outburst floods; Forget et al., 2008; Cook et al., 2016; Alcalá-Reygosa et al., 2016) and modern periglacial processes (e.g. Francou et al., 2001; Rangecroft et al., 2014). In this study we characterise the landform-sediment assemblage of Charquini Sur through detailed geomorphological mapping of the foreland, supported by sedimentological analyses. This information is used to develop the first landsystem model of a modern tropical glacier and to provide an insight into the temporal evolution of ice-marginal processes since the LIA.

\section{Study area}

Charquini Sur is a cirque glacier located on the southern side of the Cerro Charquini massif $\left(16.3^{\circ} \mathrm{S}, 68.1^{\circ} \mathrm{W} ; 5,392 \mathrm{~m}\right.$ a.s. I.) within the Cordillera Real mountain belt, $20 \mathrm{~km}$ north of Bolivia's capital city La Paz (Fig. 1). At 5,000 m a.s.l., air temperature oscillates around $0^{\circ} \mathrm{C}$ by several degrees over the seasons, resulting in frequent freeze-thaw cycles but only shallow frost penetration into the ground. Annual precipitation is $\sim 400-800 \mathrm{~mm}$, mainly falling as snow (Francou and Bertran, 1997; Francou, et al., 2001; Wagnon et al., 2001; Sicart et al., 2005). The glacier basin is wide and open and comprises Ordivician and Silurian metasedimentary rocks on the sides (slates, siltstones, gneisses) and Triassic granitoids and gneisses at its head. The basin has a floor-summit elevation range of $\sim 600 \mathrm{~m}$ and at its head consists of steep rockwalls subject to slope processes. 


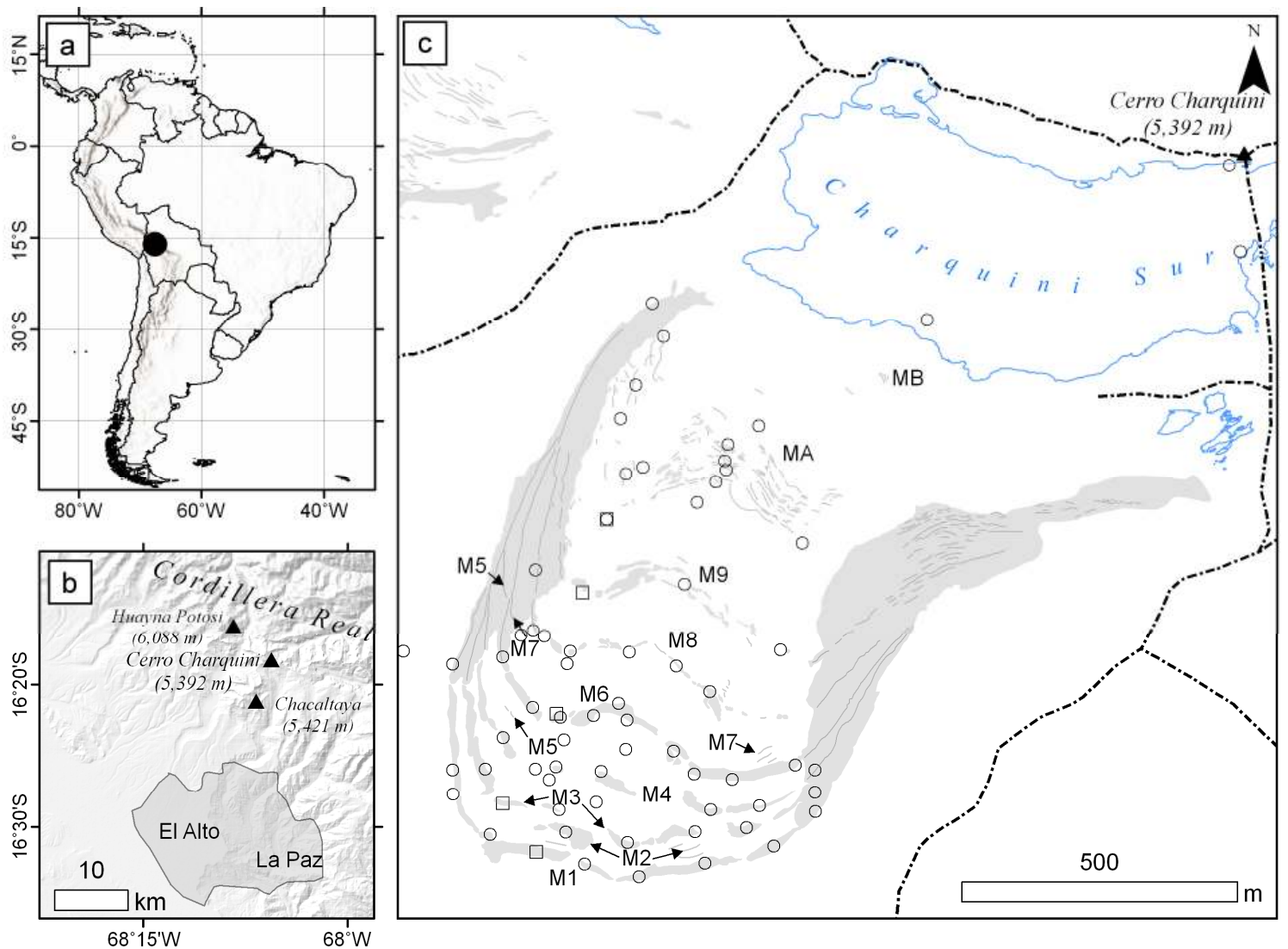

Figure 1 Location of Cerro Charquini in South America (a) and Bolivia (b). (c) Valley of Charquini Sur with the glacier outlined in blue. Grey areas are frontal and lateral moraines; M1, M2, etc. are names of successive moraine ridge suites; dashed lines are mountain ridge lines; circles are clast shape sample sites; squares are diamict sample sites.

Since the LIA maximum in the mid- $17^{\text {th }}$ century, all glaciers in Bolivia have significantly reduced in area and many of the smallest ice masses have already disappeared (Ramírez et al., 2001; Soruco et al., 2009; Rabatel et al., 2013; Cook et al., 2016). Charquini Sur is a $\sim 900 \mathrm{~m}$-wide, $\sim 500 \mathrm{~m}$-long glacier with an area of $0.3 \mathrm{~km}^{2}$. It is representative of the glaciers in the Cordillera Real, where $\sim 80 \%$ are smaller than $0.5 \mathrm{~km}^{2}$ (Jordan, 1991), and most glaciers share Charquini Sur's southerly aspect and exist at a comparable elevation range $(\sim 5,000-5,300 \mathrm{~m})$. To date, Charquini Sur has lost $\sim 75 \%$ of its area since the LIA maximum (Rabatel et al., 2008) and continues to retreat. The average specific mass balance of Charquini Sur is strongly negative at $-1.0 \mathrm{~m}$ w.e. $\mathrm{yr}^{-1}$, although with high inter-annual variability (20032013; WGMS, 2016). Ablation occurs throughout the year, with a minimum during the dry season, while snow accumulates during the austral summer (i.e. the wet season). The medium- to long-term survival prospects for Charquini Sur are poor, as Rabatel et al. (2006) reported that the long-term equilibrium line altitude (ELA) has already risen above its highest elevations. Rabatel et al. $(2005,2008)$ presented a retreat chronology for the glacier based on lichenometry and concluded its LIA maximum extent occurred in the late- $17^{\text {th }}$ century, i.e. similar to other tropical Andean glaciers. The validity of lichenometry as a method for deriving numerical ages has been questioned (e.g. Osborn et al., 2015). However, our paper does not contribute to this debate, and we choose to report the ages from Rabatel et al. (2008) in relation to each moraine ridge suite (together with original error estimates) in order to provide a general, relative chronological context.

\section{Methods}

\section{Geomorphological mapping}

Geomorphological mapping was conducted during fieldwork in 2016 and from an orthorectified multispectral Pléiades satellite image (acquired $28^{\text {th }}$ May 2013) with a pixel resolution of $0.5 \mathrm{~m}$. Fieldwork consisted of mapping landform position with a hand-held GPS, making observations and morphological descriptions, and taking photographs to help inform remote sensing interpretations. Landforms were identified in the field and from satellite imagery based on a combination of their morphology, orientation, surface texture and colour, and surface sediment characteristics (Table 1). Freely available online satellite imagery (e.g. Bing Maps and Google Earth) was used to aid interpretation. Landforms were digitized as polygons or polylines within ArcGIS. Contour lines were derived from a $1.2 \mathrm{~m}$ resolution digital elevation model generated from stereo-pairs of the Pléiades satellite images and 80 ground control points. The results of the mapping are presented in a simplified form as part of Figure 2 and as a detailed 1:4,000 scale geomorphological map in the supplementary materials. 
Table 1 Mapping criteria for classification of landforms and surface features.

\begin{tabular}{|c|c|c|}
\hline Feature & Visual appearance on satellite imagery & Sediment characteristics \\
\hline Glacier ice and snow & $\begin{array}{l}\text { White surfaces, smooth in appearance, occupying the } \\
\text { uppermost parts of cirques }\end{array}$ & \\
\hline Supraglacial debris & $\begin{array}{l}\text { Rough, brownish areas on glacier surfaces with identifiable } \\
\text { individual boulders }\end{array}$ & $\begin{array}{l}\text { Thin chaotic layer of gravel and boulders (up to } \\
\sim 20 \mathrm{~m} \text { in diameter) on the glacier surface, } \\
\text { typically of very angular and angular roundness }\end{array}$ \\
\hline $\begin{array}{l}\text { Supraglacial melt-out } \\
\text { deposits }\end{array}$ & $\begin{array}{l}\text { Irregular brownish areas of rough texture with identifiable } \\
\text { individual boulders, located proglacially and mainly along the } \\
\text { former centreline of the glacier }\end{array}$ & $\begin{array}{l}\text { Thin chaotic layer of gravel and boulders of very } \\
\text { angular and angular roundness in a proglacial } \\
\text { location }\end{array}$ \\
\hline $\begin{array}{l}\text { Supraglacial melt-out } \\
\text { boulder fields }\end{array}$ & $\begin{array}{l}\text { Zones with high density of large, black boulders located } \\
\text { proglacially within the zones of supraglacial melt-out deposits }\end{array}$ & $\begin{array}{l}\text { Clusters of large boulders (up to } \sim 5 \mathrm{~m} \text { in } \\
\text { diameter) of very angular, angular and sub- } \\
\text { angular roundness, often covered with black } \\
\text { lichens }\end{array}$ \\
\hline Large moraine ridges & $\begin{array}{l}\text { Ridges } \sim 10-200 \mathrm{~m} \text { long and up to } \sim 30 \mathrm{~m} \text { wide, forming } \\
\text { continuous arcs perpendicular or oblique to the glacier margin, } \\
\text { occasionally double-crested, light-coloured or covered by dark- } \\
\text { grey sediments }\end{array}$ & $\begin{array}{l}\text { Typical heights of } \sim 1-5 \mathrm{~m} \text {, typical surface cover of } \\
\text { dark pebble- and cobble-sized clasts of variable } \\
\text { roundness ranging from very angular to sub- } \\
\text { rounded }\end{array}$ \\
\hline Minor moraine ridges & $\begin{array}{l}\text { Short ridges oriented perpendicular or oblique to the glacier } \\
\text { front, } \sim 1-5 \mathrm{~m} \text { wide, found in groups of } \sim 2-10 \text { parallel ridges, } \\
\text { light-coloured or covered by dark-grey sediments }\end{array}$ & $\begin{array}{l}\text { Typical height of } \sim 1 \mathrm{~m} \text {, typical surface cover of } \\
\text { cobble-sized clasts of variable roundness ranging } \\
\text { from very angular to sub-angular }\end{array}$ \\
\hline Lateral moraines & $\begin{array}{l}200-600 \mathrm{~m} \text { long ridges at the foot of the valley sides, lateral } \\
\text { extensions of major moraine ridges in a frontal position, usually } \\
\text { smooth in appearance and much brighter than surrounding } \\
\text { slope deposits, clearly-defined crests, light-coloured or covered } \\
\text { by dark-grey sediments }\end{array}$ & $\begin{array}{l}\text { Extend for some } 50-100 \mathrm{~m} \text { above the foot of the } \\
\text { slope, composed of muddy sandy gravel with low } \\
\text { clast content, locally covered by darker clasts of } \\
\text { scree (slate) }\end{array}$ \\
\hline Intermorainic zones & $\begin{array}{l}\text { Low-relief surfaces between morainic ridges; ranging in colour } \\
\text { and texture from light-coloured/brownish and relatively smooth } \\
\text { to dark-grey and rough, particularly close to valley sides }\end{array}$ & $\begin{array}{l}\text { Massive, usually matrix-supported diamict, often } \\
\text { with surface cover of dark pebble- and cobble- } \\
\text { sized clasts of variable roundness ranging from } \\
\text { very angular to sub-rounded }\end{array}$ \\
\hline Flutings & $\begin{array}{l}10-200 \mathrm{~m} \text { long, } \sim 1 \mathrm{~m} \text { wide, densely-spaced stripes of brighter } \\
\text { material, located proglacially and oriented parallel to former ice } \\
\text { flow direction, usually found in larger groups on smooth } \\
\text { surfaces of the intermorainic zones }\end{array}$ & $\begin{array}{l}\text { Ridges of sandy gravel up to } \sim 0.5 \mathrm{~m} \text { high, } \\
\text { bounded by depressions filled with pebbles and } \\
\text { cobbles along the flanks }\end{array}$ \\
\hline Ice-moulded bedrock & $\begin{array}{l}\text { Outcrops of dark brown rock surfaces extending above } \\
\text { surrounding sediment-covered surfaces, usually of rounded, } \\
\text { smoothed topography }\end{array}$ & $\begin{array}{l}\text { All outcrops within the foreland show signs of } \\
\text { smoothing and striations }\end{array}$ \\
\hline Glaciofluvial sediments & $\begin{array}{l}\text { Light-grey and rough or dark-grey and smooth surface sediment } \\
\text { cover, located within scarp-bounded channels and forming } \\
\text { outwash fans, identifiable individual boulders }\end{array}$ & $\begin{array}{l}\text { Meltwater channels composed of gravel and } \\
\text { boulders of variable roundness, outwash plains } \\
\text { composed of sand and sub-angular to sub- } \\
\text { rounded pebble-sized clasts }\end{array}$ \\
\hline $\begin{array}{l}\text { Streams (active or } \\
\text { intermittent) }\end{array}$ & $\begin{array}{l}\text { Linear sinuous water courses surrounded by glaciofluvial } \\
\text { sediments, many hundreds of metres long and }<1 \mathrm{~m} \text { wide, } \\
\text { emerging from the terminus and extending down-valley or } \\
\text { appearing discontinuous, particularly in boulder-dominated } \\
\text { areas, also in extraglacial locations }\end{array}$ & \\
\hline $\begin{array}{l}\text { Abandoned meltwater } \\
\text { channels }\end{array}$ & $\begin{array}{l}\text { Linear features, } \sim 10-250 \mathrm{~m} \text { long, } \sim 1-10 \mathrm{~m} \text { wide, incised into } \\
\text { smooth and bright intermorainic zones and glaciofluvial } \\
\text { sediments, currently contain no water }\end{array}$ & \\
\hline Scarps & $\begin{array}{l}\text { Cliff-like features with a sharp change in brightness at the head, } \\
\text { commonly bounding glaciofluvial sediments }\end{array}$ & \\
\hline Rockwalls & $\begin{array}{l}\text { Steep, sediment-free, dark-brown or grey surfaces extending } \\
\text { above the valley sides and headwall, rough and cracked in } \\
\text { appearance, strong brightness gradients due to shading }\end{array}$ & Slate-dominated valley sides, granitic headwall \\
\hline Talus & $\begin{array}{l}\text { Fans of loose scree deposits between rockwalls and valley floor } \\
\text { or lateral moraines, brown-coloured and relatively smooth in } \\
\text { appearance }\end{array}$ & $\begin{array}{l}\text { Plate-shaped angular slate clasts on the sides of } \\
\text { the valley of very angular to sub-angular } \\
\text { roundness }\end{array}$ \\
\hline Rockglaciers & $\begin{array}{l}\text { Talus-covered tongues with a convex cross-section, } \sim 200-300 \\
\mathrm{~m} \text { long, } \sim 80-130 \mathrm{~m} \text { wide, identifiable surface flow lines, sharp } \\
\text { crest at the front }\end{array}$ & \\
\hline $\begin{array}{l}\text { Fine-grained } \\
\text { weathering sheets }\end{array}$ & $\begin{array}{l}\text { Patches of loose, light-coloured, fine sediments covering talus } \\
\text { slopes, smooth texture, typically emerging just beneath } \\
\text { rockwalls }\end{array}$ & $\begin{array}{l}\text { Fine slope sediments resulting from weathering of } \\
\text { local rocks }\end{array}$ \\
\hline Sorted stripes & $\begin{array}{l}\text { Densely spaced bright and dark stripes on fine-grained } \\
\text { weathering sheets, up to } \sim 200 \mathrm{~m} \text { long, }<1 \mathrm{~m} \text { wide, oriented } \\
\text { downslope }\end{array}$ & $\begin{array}{l}\text { Signs of periglacial sorting on fine-grained } \\
\text { weathering sheets }\end{array}$ \\
\hline
\end{tabular}

\section{$\underline{\text { Sedimentological analyses }}$}

The sediment compositions of different landforms and surfaces across the foreland were investigated in order to aid interpretations of features and to help determine sediment transport pathways. Sediment types were described 
according to their physical characteristics following Evans and Benn (2004), including range of grain sizes, degree of sorting, and texture. Clast shape and roundness were measured at 66 sites chosen as being representative of the range of different landforms and/or surface sediment types (Fig. 1C). Except for the slate-dominated talus slopes, the sampled clasts $(n=50$ per sample) were exclusively granitoids, which is the dominant lithology in the study area, and the sampling and statistical processing (RA and $\mathrm{C}_{40}$ indices) followed standard procedures outlined in Lukas et al. (2013). Five samples were also collected for particle-size analyses from the surfaces of moraine ridges and an intermorainic zone. Particle-size distributions were derived through a combination of sieving (11.2 $\mathrm{mm}$ to $100 \mu \mathrm{m})$ and laser granulometry $(<100 \mu \mathrm{m})$.

\section{Moraine coding}

Rabatel et al. $(2005,2006)$ coded the Charquini Sur sequence of moraine ridge suites from M1 to M10, with M1 representing the lowest-elevation and oldest ridges, and M10 the youngest ridges. We adopt a similar notation in this paper, with some minor modifications, in order to be consistent with the previous work. Our coding diverges from Rabatel et al. $(2005,2006)$ in relation to the poorly-preserved moraines coded as M10 in their study, which are found at the immediate forefront of a larger group of previously unreported ridges. We have grouped all of these ridges under the new code Minor Moraines A (notation MA). Additionally, an innermost (youngest) suite of ridges exposed since the previous work of Rabatel et al. $(2005,2006)$ has been given the code Minor Moraines B (notation MB) (Fig. 1c).

\section{The landform-sediment assemblage of the Charquini Sur foreland}

\section{Moraine ridge suites}

The foreland of Charquini Sur displays seven moraine ridge suites spanning the full width of the foreland between the lateral moraines (M1, M3, M4, M6, M8, M9, MA) and a further four suites that are more fragmentary and not as well developed (M2, M5, M7, MB) (Figs 1, 2 and 3a). Typically, moraine ridges are arcuate in planform and some (M4, M6) clearly overtop older ridges. Moraine ridges are usually 1-5 m high, $<20 \mathrm{~m}$ wide and have symmetric proximal and distal slopes inclined at $\sim 20-50^{\circ}$. Most ridges have rounded tops (Fig. 3a), although some are crested in places (M1, M3, M4, M6, MB), double-crested (M3, M6), or draped by flutings on their proximal slopes (M6). Some suites comprise groups of 2-10 parallel ridges (M2, M7, M9, MA, MB), whereas other suites consist of single ridges. No evidence indicative of degrading ice cores was found in any of the moraine ridges (e.g. debris flows, surface tension cracks, or water seepage at their base). Details of moraine ridge suite morphological characteristics, together with their basic sedimentological information, are summarized in Tables 2 and 3.

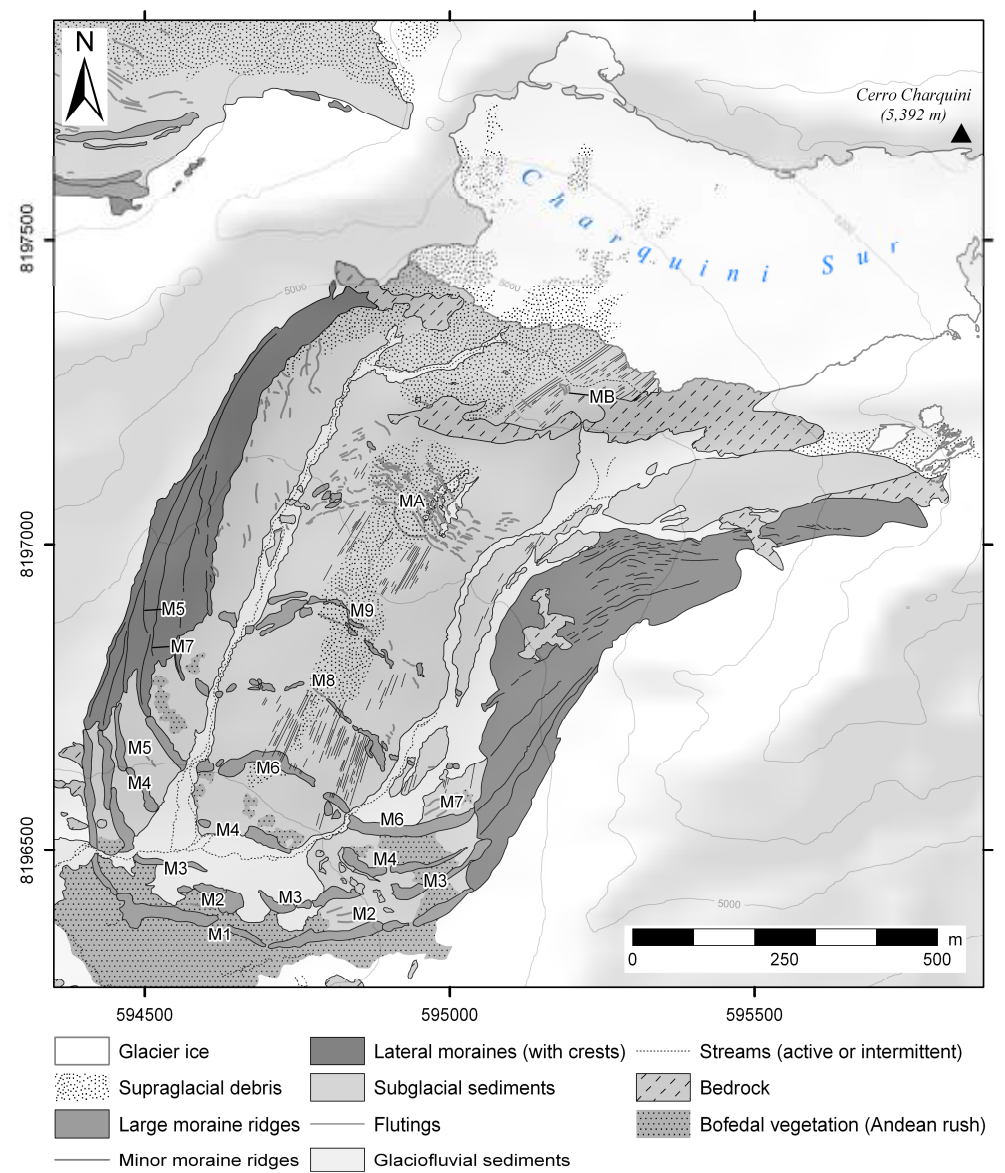

Figure $\mathbf{2}$ Geomorphological map of Charquini Sur foreland. A more detailed version can be found in the supplementary materials. 

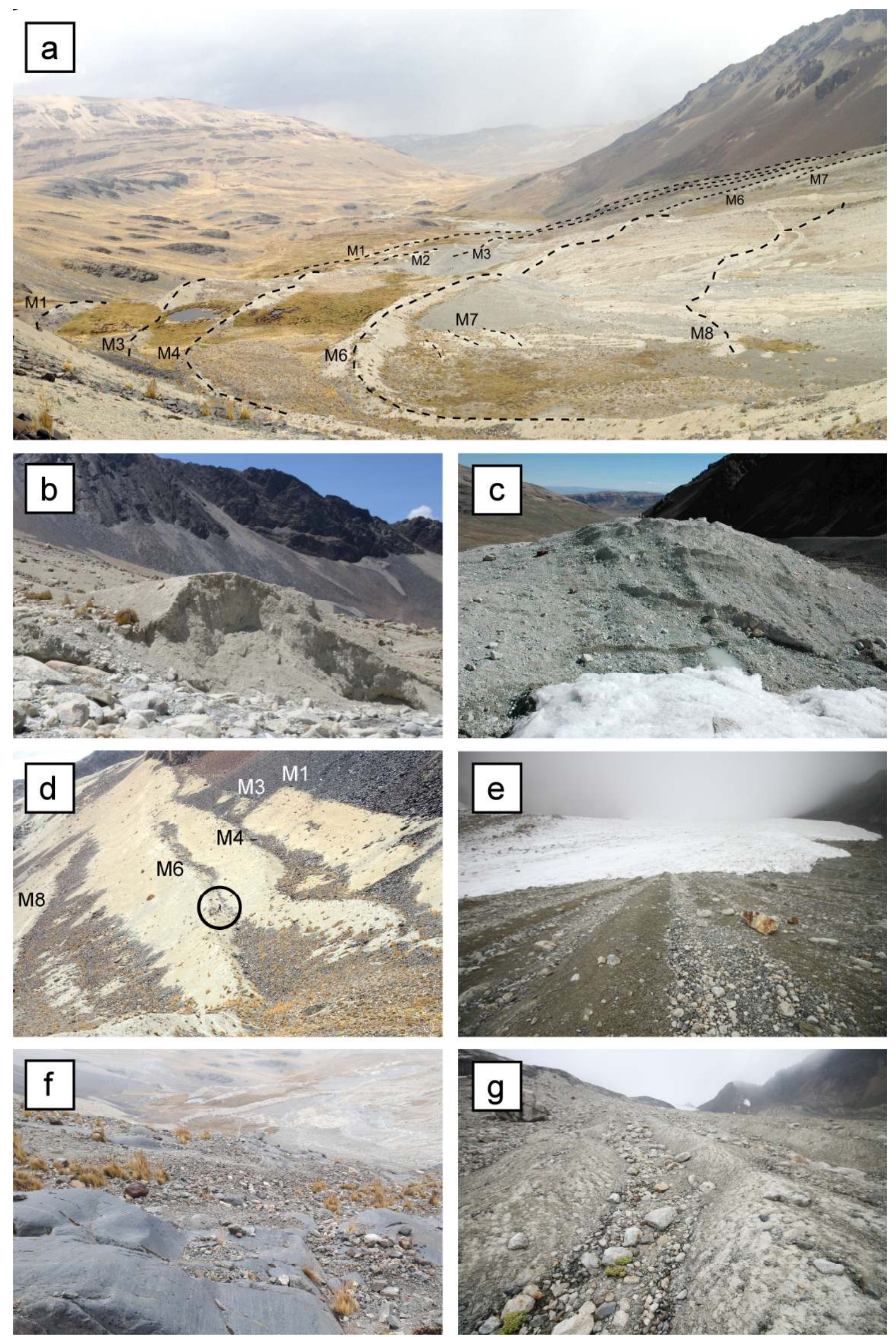

Figure 3 (a) The lowest part of the Charquini Sur foreland showing moraine ridges M1-M8. View is from the eastern lateral moraine. (b) Exposure within an M9 moraine ridge showing its clast-poor matrix-supported diamict composition. (c) Small moraine ridge complex MB close to the glacier front (photographed in 2005). Note the small ridge parallel and adjacent to the glacier front. (d) Eastern lateral moraines with well developed crests. Person circled for scale. (e) Flutings emerging from beneath the eastern section of the glacier margin. (f) Small ice-moulded bedrock outcrops within the eastern lateral moraine. $(\mathrm{g})$ Abandoned meltwater channel incised into an intermorainic plain and filled with glacifluvial sediments. 
There appears to be a change in spacing between different moraine ridge suites within the foreland. The spacing between moraine ridge suites in the lower part of the foreland (e.g. M1-M6) is fairly uniform at $\sim 30-60 \mathrm{~m}$. Between the $\mathrm{M} 6$ ridges and the $\mathrm{M9}$ ridges, the spacing between ridge suites increases slightly to $\sim 120-150 \mathrm{~m}$. The largest spacing between ridge suites is found in the uppermost part of the foreland, between the M9-MA-MB suites $(\sim 200-300 \mathrm{~m})$. Moraine ridges are notably less common closest to the modern ice margin. A distinct up-valley trend of decreasing moraine size and changes in morphology is also evident (Fig. 2). In the lowermost part of the foreland, moraine ridge suites M1-M4 and M6 ( 2-6 m high) span the entire width of the valley. In the central part, the M8 and M9 moraine ridge suites are equally as well preserved, but ridges are much smaller. Towards the glacier front, the MA ridge suite $(\sim 1-2 \mathrm{~m}$ high) is composed of multiple thin, discrete ridges which also extend to the valley sides. The MB suite is spatially-restricted to $\sim 30 \mathrm{~m}$ wide zone and consists of a close grouping of small ridges $\sim 0.5-1 \mathrm{~m}$ in height and located on the ice-proximal side of a small bedrock high (i.e. a reverse slope). One of the minor ridges within the MB suite was observed to have formed in 2005 following a low-ablation dry season (Fig. 3c).

Most moraine ridges (i.e. M1-M8) are composed of a sandy/silty matrix-supported diamict (Fig. 4a), with generally a low to moderate clast content. The higher-elevated suites M9, MA and MB contain a much lower proportion of silt, with the innermost MB suite comprised almost exclusively of angular pebble-sized clasts and sand. Clasts found within the near-surface layer of most moraine ridges across the foreland (sampled away from areas where the moraine is clearly draped by supraglacial debris, see below) are dominated by angular and sub-angular classes (Figs. $4 \mathrm{~b}$ and 5 ), and there is a clear trend of increasing clast roundness in a down-valley direction (Table 3). Granitoid lithology clasts that are predominant across the study foreland usually lack evidence of glacial imprinting, in contrast to the sporadic sedimentary lithologies, which are commonly striated and/or faceted. Two exposures dissected by the western proglacial stream within small ( 2 $\mathrm{m}$ high) ridges of the M6 and M9 suites display stratified matrix-supported diamict with discrete, down-valley-dipping layering. The layering is oriented broadly parallel to the surface of the ridges, with some apparent minor folding also visible (Figs. $3 b$ and 6 ). The internal structure of larger moraines was not investigated.

The lateral moraines of Charquini Sur provide a clear indication of decreasing glacier thickness since the LIA (Fig. 3d). Both eastern and western lateral moraine complexes extend for some 50-100 m above the foreland and exhibit welldeveloped multiple crests, which prevent them from being buried by scree from the surrounding valley sides by trapping rockfall-derived debris into small valleys between the crests and slopes. The eastern lateral moraine displays an uninterrupted pattern of retreat and lateral margin positions for the M1, M3, M4, M6, M8 and M9 suites, clearly traceable into their frontal counterparts, as well as a number of short crest fragments related to the MA suite. The western lateral moraine records these same positions except for the MA suite, and also preserves traces of the M5 and M7 suites. It is notable that no lateral ridges correlating to the M2 frontal ridges can be identified on either side of the foreland. The western lateral moraine contains evidence for partial overtopping of older ridge crests by younger ridges, i.e. M3 by M4, and M5 by M6 (Fig. 2; Table 2). Clasts within the lateral moraines are predominantly angular and sub-angular (Fig. 5).

\section{Flutings and intermorainic zones}

Between the moraine ridge suites there are groups of distinct, parallel-sided, densely-spaced flutings. Groups of flutings are found on gently inclined surfaces in zones M6-M8, M9-MA, and have been exposed at the receding ice margin since the 1990s (Fig. 3e). The largest flutings are in the group at the ice margin, exceeding $\sim 200 \mathrm{~m}$ in length, $\sim 1 \mathrm{~m}$ in width and $\sim 0.5 \mathrm{~m}$ in height. The flutings are composed of diamict (in the lower foreland) or sandy gravel (at the ice margin), with pebble-sized clasts aligned along the flanks. Some flutings are associated with boulders at their upvalley extents.

Flutings in the lower foreland are superimposed on low-relief intermorainic zones composed of diamict. The sediment within the intermorainic zones (e.g. in zones M1-M8) is visually similar to the diamict found on moraine ridges, i.e. a sandy/silty matrix-supported diamict with a predominance of angular and sub-angular clasts. In this relatively clastpoor zone, the thickness of the sediment cover is typically $\sim 1 \mathrm{~m}$, and ice-moulded bedrock protuberances are commonly exposed. In the zone M9-MA, the surface sediment cover appears sandier and thinner $(<1 \mathrm{~m})$ than in the lower foreland. To the east, however, it reaches a thickness of several metres, as suggested by deep gullies eroded into the diamict by the eastern proglacial stream. Flutings close to the modern margin overlay a loosely-packed surface sediment, dominated by angular pebble-sized clasts and sand (Fig. 3e), generally resembling that within the neighbouring $\mathrm{MB}$ moraine ridges. The sediment thickness in the uppermost part of the foreland is very low and the sediment cover is discontinuous.

Ice-moulded bedrock

Bedrock outcrops emerge from beneath the thin intermorainic zone sediments in several places across the foreland. Ice-moulded bedrock is common and virtually all outcrops within the M1 zone display signs of abrasion and striations (Fig. 3f). The largest outcrop, the distinct bedrock threshold located in the upper part of the foreland, is a classic roche moutonnée with a smoothed proximal side and a steep, rough step on the lee-side. At its debris-free summit, well preserved grooves are exposed in close proximity to flutings emerging from beneath the glacier margin. 
Table 2 Summary of morphological and sedimentological characteristics of moraine ridge suites in the Charquini Sur foreland.

\begin{tabular}{|c|c|c|c|c|c|c|c|c|c|c|c|}
\hline & M1 & M2 & M3 & M4 & M5 & M6 & M7 & M8 & M9 & MA & MB \\
\hline $\begin{array}{l}\text { Suggested } \\
\text { age }^{*}\end{array}$ & $1686 \pm 26$ & $1703 \pm 25$ & $1734 \pm 21$ & $1765 \pm 17$ & $n / d$ & $1808 \pm 14$ & $1825 \pm 17$ & $1843 \pm 16$ & $1871 \pm 23$ & $\begin{array}{c}\text { pre- } \\
\text { 1940s- } \\
1980 \text { s }\end{array}$ & Early-2000s \\
\hline $\begin{array}{l}\text { General } \\
\text { character }\end{array}$ & $\begin{array}{l}\text { Prominent } \\
\text { cross- } \\
\text { valley } \\
\text { moraine } \\
\text { arc }\end{array}$ & $\begin{array}{l}\text { Prominent } \\
\text { individual } \\
\text { ridges }\end{array}$ & $\begin{array}{l}\text { Prominent } \\
\text { cross- } \\
\text { valley } \\
\text { moraine } \\
\text { arc }\end{array}$ & $\begin{array}{l}\text { Prominent } \\
\text { cross- } \\
\text { valley } \\
\text { moraine } \\
\text { arc }\end{array}$ & $\begin{array}{l}\text { Minor } \\
\text { individual } \\
\text { ridges }\end{array}$ & $\begin{array}{l}\text { Prominent } \\
\text { cross- } \\
\text { valley } \\
\text { moraine } \\
\text { arc }\end{array}$ & $\begin{array}{l}\text { Minor } \\
\text { individual } \\
\text { ridges }\end{array}$ & $\begin{array}{l}\text { Minor } \\
\text { cross- } \\
\text { valley } \\
\text { moraine } \\
\text { arc }\end{array}$ & $\begin{array}{l}\text { Minor cross- } \\
\text { valley } \\
\text { moraine arc }\end{array}$ & $\begin{array}{l}\text { Minor } \\
\text { cross- } \\
\text { valley } \\
\text { moraine } \\
\text { arc of } \\
\text { parallel } \\
\text { ridges }\end{array}$ & $\begin{array}{c}\text { Confined } \\
\text { grouping of } \\
\text { minor parallel } \\
\text { ridges }\end{array}$ \\
\hline $\begin{array}{l}\text { Related } \\
\text { lateral } \\
\text { moraine } \\
\text { crest }\end{array}$ & Yes & No & Yes & Yes & Yes & Yes & Yes & Yes & Yes & Yes & No \\
\hline $\begin{array}{l}\text { Typical } \\
\text { height }\end{array}$ & $2-4 m$ & $1-3 m$ & $3-5 m$ & $2-3 m$ & $1 \mathrm{~m}$ & $2-6 m$ & $1 \mathrm{~m}$ & $1-2 m$ & $1-2 m$ & $1-2 m$ & $0.5-1 \mathrm{~m}$ \\
\hline $\begin{array}{l}\text { Typical } \\
\text { width } \\
\text { (max. } \\
\text { width) }\end{array}$ & $\begin{array}{c}10-20 \mathrm{~m} \\
\text { (max. } 25 \\
\mathrm{~m})\end{array}$ & $\begin{array}{c}10-20 \mathrm{~m} \\
(\max .40 \mathrm{~m})\end{array}$ & $\begin{array}{c}10-20 \mathrm{~m} \\
(\max .22 \\
\mathrm{m})\end{array}$ & $\begin{array}{c}15 \mathrm{~m} \\
(\max .22 \\
\mathrm{m})\end{array}$ & $2 \mathrm{~m}$ & $\begin{array}{c}15-20 \mathrm{~m} \\
(\max .30 \\
\mathrm{m})\end{array}$ & $4 \mathrm{~m}$ & $\begin{array}{c}5-10 \mathrm{~m} \\
(\max .20 \\
\mathrm{m})\end{array}$ & $\begin{array}{c}5-10 \mathrm{~m} \\
(\max .25 \mathrm{~m})\end{array}$ & $\begin{array}{c}<5 \mathrm{~m} \\
(\max .25 \\
\mathrm{m})\end{array}$ & $1-2 m$ \\
\hline $\begin{array}{l}\text { Moraine } \\
\text { surface }\end{array}$ & $\begin{array}{l}\text { Rounded } \\
\text { or crested }\end{array}$ & Rounded & $\begin{array}{l}\text { Crested or } \\
\text { double- } \\
\text { crested }\end{array}$ & Rounded & Rounded & $\begin{array}{l}\text { Rounded } \\
\text { or double- } \\
\text { crested }\end{array}$ & Rounded & Rounded & Rounded & Rounded & $\begin{array}{l}\text { Rounded or } \\
\text { crested }\end{array}$ \\
\hline $\begin{array}{l}\text { Dominant } \\
\text { surface } \\
\text { sediment } \\
\text { type }\end{array}$ & $\begin{array}{l}\text { Matrix- } \\
\text { supported } \\
\text { diamict; } \\
\text { boulder- } \\
\text { enriched } \\
\text { to the } \\
\text { west }\end{array}$ & $\begin{array}{l}\text { Matrix- } \\
\text { supported } \\
\text { diamict }\end{array}$ & $\begin{array}{l}\text { Matrix- } \\
\text { supported } \\
\text { diamict, } \\
\text { boulder- } \\
\text { enriched to } \\
\text { the west }\end{array}$ & $\begin{array}{l}\text { Matrix- } \\
\text { supported } \\
\text { diamict, } \\
\text { clast- } \\
\text { enriched } \\
\text { to the } \\
\text { west }\end{array}$ & Boulders & $\begin{array}{l}\text { Matrix- } \\
\text { supported } \\
\text { diamict }\end{array}$ & $\begin{array}{l}\text { Matrix- } \\
\text { supported } \\
\text { diamict }\end{array}$ & $\begin{array}{l}\text { Matrix- } \\
\text { supported } \\
\text { diamict }\end{array}$ & $\begin{array}{l}\text { Matrix- } \\
\text { supported } \\
\text { diamict }\end{array}$ & $\begin{array}{l}\text { Matrix- } \\
\text { supported } \\
\text { diamict; } \\
\text { surficial } \\
\text { boulder } \\
\text { cover }\end{array}$ & $\begin{array}{l}\text { Pebble-sized } \\
\text { clasts and } \\
\text { sand }\end{array}$ \\
\hline $\begin{array}{c}\text { Diamict } \\
\text { matrix } \\
(<2 \mathrm{~mm} \\
\text { fractions })\end{array}$ & Sandy silt & $n / d$ & Sandy silt & $n / d$ & $n / d$ & Sandy silt & $n / d$ & $\mathrm{n} / \mathrm{d}$ & Silty sand & $n / d$ & $\mathrm{n} / \mathrm{a}$ \\
\hline $\begin{array}{l}\text { Distinct } \\
\text { features }\end{array}$ & $\begin{array}{l}\text { Partly } \\
\text { vegetated } \\
\text { with } \\
\text { lichens } \\
\text { and grass } \\
\text { The } \\
\text { lowermost } \\
\text { ridges, } \\
\text { deposited } \\
\text { on peat }\end{array}$ & $\begin{array}{l}\text { Partly eroded } \\
\text { by proglacial } \\
\text { streams of the } \\
\text { outwash plain } \\
\text { Central } \\
\text { section: } \\
\text { parallel ridges } \\
\text { situated } 20 \mathrm{~m} \\
\text { apart, } 100 \\
\text { long } \\
\text { Eastern } \\
\text { section: three } \\
\text { minor parallel } \\
\text { ridges, } 15 \mathrm{~m} \\
\text { apart, up to } \\
75 \mathrm{~m} \text { long } \\
\text { No } \\
\text { corresponding } \\
\text { ridges found } \\
\text { in the lateral } \\
\text { moraine }\end{array}$ & $\begin{array}{l}\text { Partly } \\
\text { overtopped } \\
\text { by more } \\
\text { recent M4 } \\
\text { ridge } \\
\text { Partly } \\
\text { eroded by } \\
\text { proglacial } \\
\text { streams of } \\
\text { the } \\
\text { outwash } \\
\text { plain }\end{array}$ & $\begin{array}{l}\begin{array}{l}\text { Partly } \\
\text { overtops } \\
\text { older M3 } \\
\text { ridge }\end{array} \\
\text { Central } \\
\text { section } \\
\text { partly } \\
\text { eroded by } \\
\text { proglacial } \\
\text { meltwater }\end{array}$ & $\begin{array}{l}\text { Nearly } \\
\text { completely } \\
\text { overtopped } \\
\text { by more } \\
\text { recent M6 } \\
\text { ridge } \\
\text { Only one } \\
\text { small } \\
\text { degraded } \\
\text { ridge and a } \\
\text { short } \\
\text { fragment } \\
\text { of lateral } \\
\text { moraine }\end{array}$ & $\begin{array}{l}\text { Nearly } \\
\text { completely } \\
\text { overtops } \\
\text { older M5 } \\
\text { ridge } \\
\text { Contains } \\
\text { largest } \\
\text { individual } \\
\text { ridge in } \\
\text { foreland } \\
\text { Central } \\
\text { section } \\
\text { wide, low } \\
\text { and } \\
\text { draped } \\
\text { with } \\
\text { flutings } \\
\text { from ice- } \\
\text { proximal } \\
\text { side }\end{array}$ & 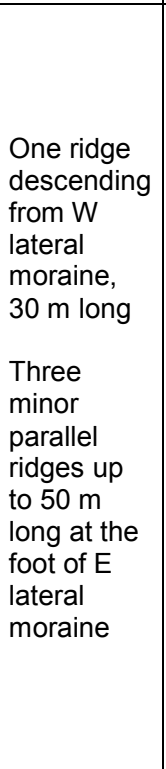 & $\begin{array}{l}\text { Intersects } \\
\text { a boulder } \\
\text { field in } \\
\text { the } \\
\text { central } \\
\text { section, } \\
\text { where it } \\
\text { forms a } \\
\text { minor } \\
\text { boulder } \\
\text { wall, } 0.5 \\
\mathrm{~m} \text { high }\end{array}$ & $\begin{array}{l}\text { Most ridges } \\
\text { have } \\
\text { parallel } \\
\text { counterparts } \\
\text { located 10- } \\
30 \mathrm{~m} \text { apart } \\
\\
\text { Intersects a } \\
\text { boulder field } \\
\text { in the } \\
\text { central } \\
\text { section, } \\
\text { where it } \\
\text { forms a } \\
\text { minor } \\
\text { boulder } \\
\text { wall, } 0.5 \mathrm{~m} \\
\text { high }\end{array}$ & $\begin{array}{l}\text { Ca. 10 } \\
\text { small } \\
\text { ridges } \\
\text { spaced 2- } \\
10 \mathrm{~m} \\
\text { apart } \\
\\
\text { Very } \\
\text { slightly } \\
\text { sinuous } \\
\text { course of } \\
\text { individual } \\
\text { ridges } \\
\text { Intersects } \\
\text { a boulder } \\
\text { field, } \\
\text { where it } \\
\text { forms a } \\
\text { large, } 2 \mathrm{~m} \\
\text { high } \\
\text { boulder } \\
\text { wall }\end{array}$ & $\begin{array}{l}\text { Ca. } 6 \text { small } \\
\text { ridges spaced } \\
3-5 \mathrm{~m} \text { apart, } \\
\text { up to } 30 \mathrm{~m} \\
\text { long } \\
\text { Ridges } \\
\text { superimposed } \\
\text { on flutings } \\
\text { The } \\
\text { innermost } \\
\text { minor ridge } \\
\text { observed to } \\
\text { have formed } \\
\text { following a } \\
\text { low-ablation } \\
\text { dry season in } \\
2005\end{array}$ \\
\hline
\end{tabular}

* based on Rabatel et al. (2008) lichenometric study (in italics) or the observed front positions

\section{Meltwater channels and outwash fans}

Present-day meltwater drainage is restricted to two small proglacial streams on the western and eastern sides of the foreland. The stream channels are filled with sediments ranging from mud to boulders, with sub-angular and subrounded being the most common roundness classes (although this varies spatially) (Table 3). 
very angular; A - angular; SA - sub-angular; SR - sub-rounded; R - rounded; WR - well rounded. Mean roundness calculated from the

Powers (1953) scale.

\begin{tabular}{|c|c|c|c|c|c|c|c|c|c|c|c|}
\hline \multirow[b]{2}{*}{ Facies } & \multirow[b]{2}{*}{$R A$} & \multirow[b]{2}{*}{$C_{40}$} & \multirow[b]{2}{*}{\begin{tabular}{|l|} 
Mean \\
roundness
\end{tabular}} & \multicolumn{6}{|c|}{$\begin{array}{l}\text { Roundness classes (relative abundance, } \\
\% \text { ) }\end{array}$} & \multicolumn{2}{|c|}{ Sample size } \\
\hline & & & & VA & A & SA & SR & $\mathbf{R}$ & WR & Clasts & Sites \\
\hline Talus (valley sides) & $92 \%$ & $73 \%$ & 0.19 & 35 & 57 & 8 & 0 & 0 & 0 & 100 & 2 \\
\hline Supraglacial debris & $96 \%$ & $45 \%$ & 0.18 & 51 & 45 & 4 & 0 & 0 & 0 & 150 & 3 \\
\hline $\begin{array}{l}\text { Supraglacial melt-out } \\
\text { drape }\end{array}$ & $94 \%$ & $43 \%$ & 0.19 & 38 & 56 & 5 & 1 & 0 & 0 & 450 & 9 \\
\hline Intermorainic zones & $60 \%$ & $28 \%$ & 0.24 & 14 & 46 & 33 & 7 & 0 & 0 & 450 & 9 \\
\hline $\begin{array}{l}\text { Frontal moraine } \\
\text { ridges (overall): }\end{array}$ & $57 \%$ & $18 \%$ & 0.25 & 8 & 49 & 36 & 7 & 0 & 0 & 1400 & 28 \\
\hline$-M 1$ & $37 \%$ & $24 \%$ & 0.28 & 5 & 32 & 49 & 12 & 1 & 0 & 250 & 5 \\
\hline$-M 2$ & $42 \%$ & $16 \%$ & 0.26 & 6 & 36 & 56 & 2 & 0 & 0 & 50 & 1 \\
\hline$-M 3$ & $46 \%$ & $15 \%$ & 0.26 & 6 & 40 & 48 & 5 & 0 & 0 & 250 & 5 \\
\hline$-M 4$ & $53 \%$ & $12 \%$ & 0.26 & 3 & 50 & 36 & 12 & 0 & 0 & 200 & 4 \\
\hline$-M 6$ & $61 \%$ & $17 \%$ & 0.25 & 11 & 51 & 32 & 7 & 0 & 0 & 400 & 8 \\
\hline$-M 8$ & $86 \%$ & $24 \%$ & 0.21 & 12 & 74 & 12 & 1 & 0 & 0 & 250 & 5 \\
\hline Lateral moraines & $49 \%$ & $13 \%$ & 0.26 & 4 & 45 & 41 & 10 & 0 & 0 & 300 & 6 \\
\hline $\begin{array}{l}\text { Glaciofluvial } \\
\text { sediments (overall): }\end{array}$ & $17 \%$ & $18 \%$ & 0.34 & 2 & 15 & 40 & 40 & 4 & 0 & 350 & 7 \\
\hline $\begin{array}{l}\text {-Channels of active } \\
\text { streams }\end{array}$ & $19 \%$ & $20 \%$ & 0.32 & 2 & 17 & 45 & 35 & 2 & 0 & 300 & 6 \\
\hline -Outwash plain & $2 \%$ & $6 \%$ & 0.42 & 0 & 2 & 10 & 72 & 16 & 0 & 50 & 1 \\
\hline
\end{tabular}

Aside from within the main channels, the deposition of glaciofluvial material primarily occurs in low-gradient areas in the lowest part of the foreland. Here, outwash fans composed of sand and pebble-sized clasts have formed immediately inside and outside of the main M1 moraine ridge. The largest outwash plain $(\sim 270 \mathrm{~m} \times 100 \mathrm{~m})$ is located in the zone M1-M4, and partly buries the base of the M1-M3 moraine ridges. Clast measurements at a single site on the outwash fan immediately down-valley of the M1 ridge suite exhibited the highest average roundness recorded in the study area (Figs. 4 and 5c; Table 3).

In steeper areas of the foreland, meltwater has cut channels and scarps of various sizes (see Supplementary Map). The channels are particularly clear in the steep, high-elevation niche on the eastern side of the basin. Here, the channels form a labyrinth of deeply-incised gullies and scarps, the largest of which is $\sim 20 \mathrm{~m}$ in height, gradually decreasing to 1-2 metres in depth in the central section of the eastern proglacial stream. Smaller inactive channels are also frequently observed along the margins of the two active proglacial streams, typically aligned parallel to adjacent moraine ridges (Fig. $3 g$ ).

\section{Supraglacial debris}

The Charquini Sur glacier surface is largely debris-free (clean) with some thin patches of supraglacial debris cover, particularly on its western side (Fig. 7a). No distinct ridges are identifiable within the supraglacial debris cover. Typically, the debris consists of granitic and gneiss pebble- and cobble-sized clasts and boulders, the largest of which is over $20 \mathrm{~m}$ long, with lower concentrations of finer fractions. The debris is almost exclusively angular or very angular and displays the lowest levels of clast modification in the study area. 

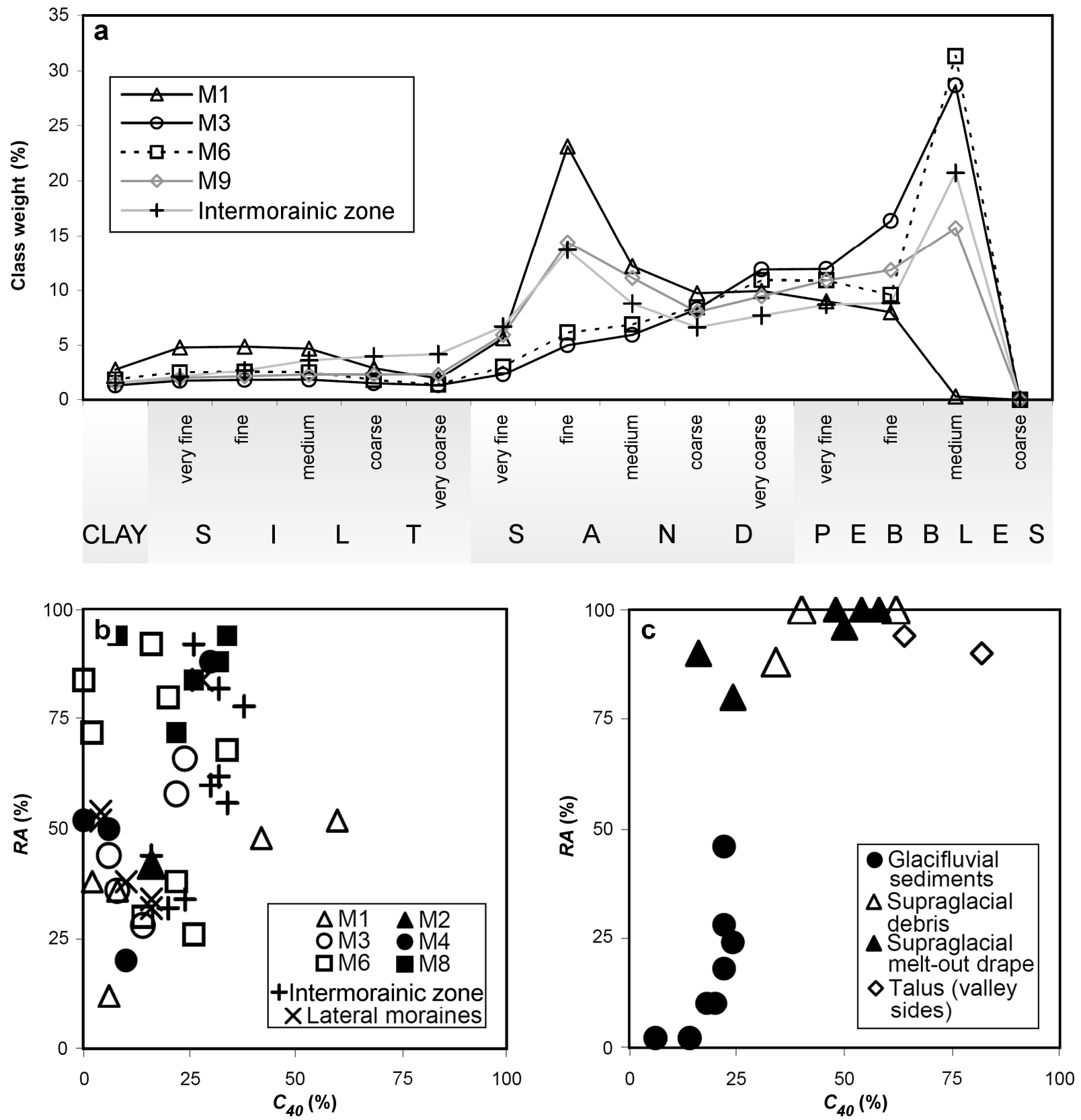

Figure 4 (a) Distribution of particle-size classes (after Blott \& Pye, 2001) of sediment samples. (b, c) RA/C40 plots for moraine ridges, intermorainic plains and surface sediment types. See Lukas et al. (2013) for comparison of these data with fluvial, talus and subglacial control envelopes collected from a range of glacial environments and different clast lithologies.

Supraglacial debris is also observed melting-out from the western part of the glacier front, forming a thin supraglacial drape overlying the subglacial surface. The drape is a loose, poorly-sorted boulder gravel, which closely resembles the debris cover on the glacier surface (Fig. 4; Table 3). This debris covers a zone $\sim 350 \mathrm{~m}$ wide adjacent to the western margin. A similar surface cover of angular sediment, disconnected from the current ice margin, extends as a $\sim 700 \mathrm{~m}$ longitudinal belt that gradually widens up-valley from the outwash plain in the lower part of the foreland to the bedrock threshold. The belt is draped on moraine ridges in several places. There are several clusters of large angular blocks 

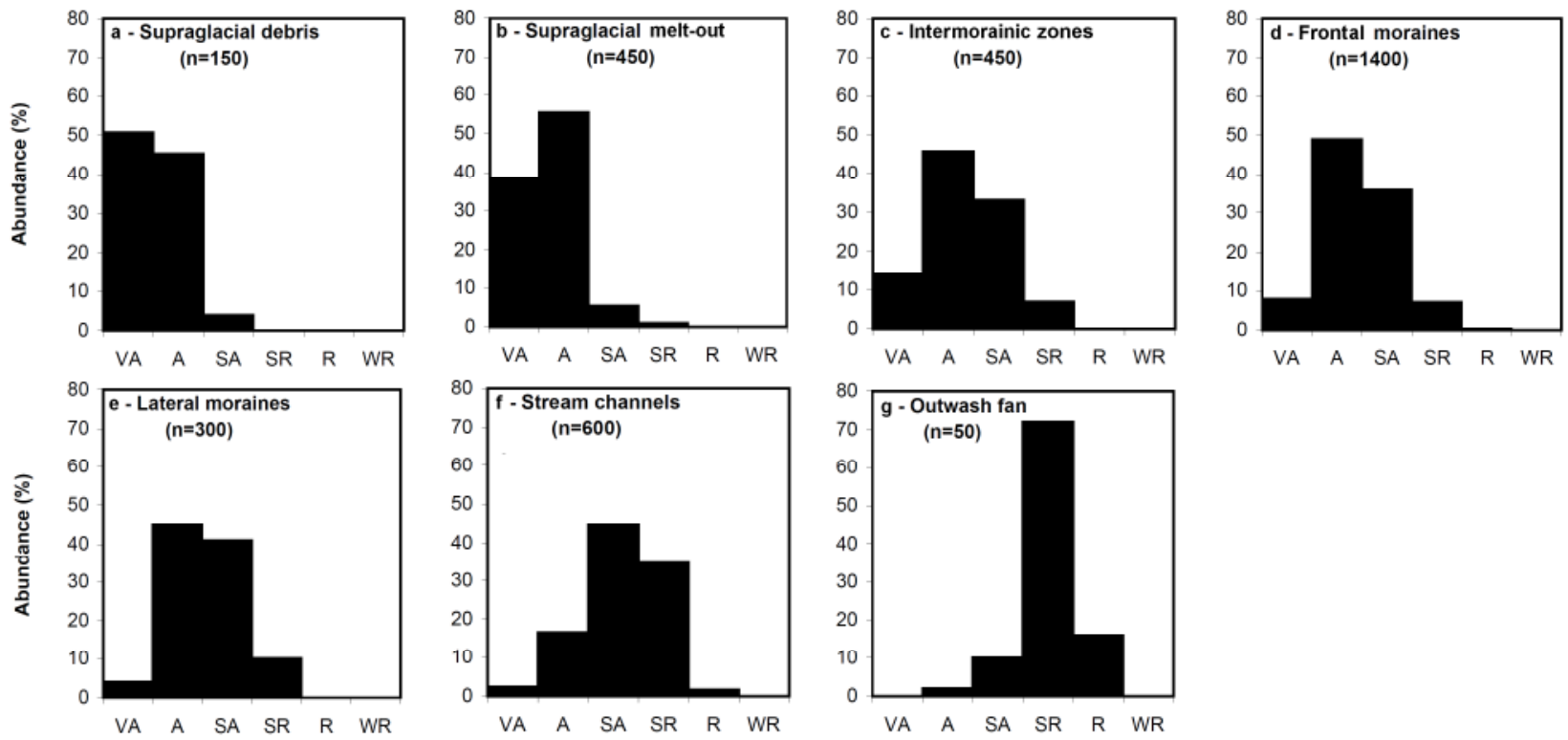

Figure 5 Clast roundness histograms for different landform complexes (VA - very angular; A - angular; SA - sub-angular; SR - sub-rounded; $R$ - rounded; WR - well rounded).
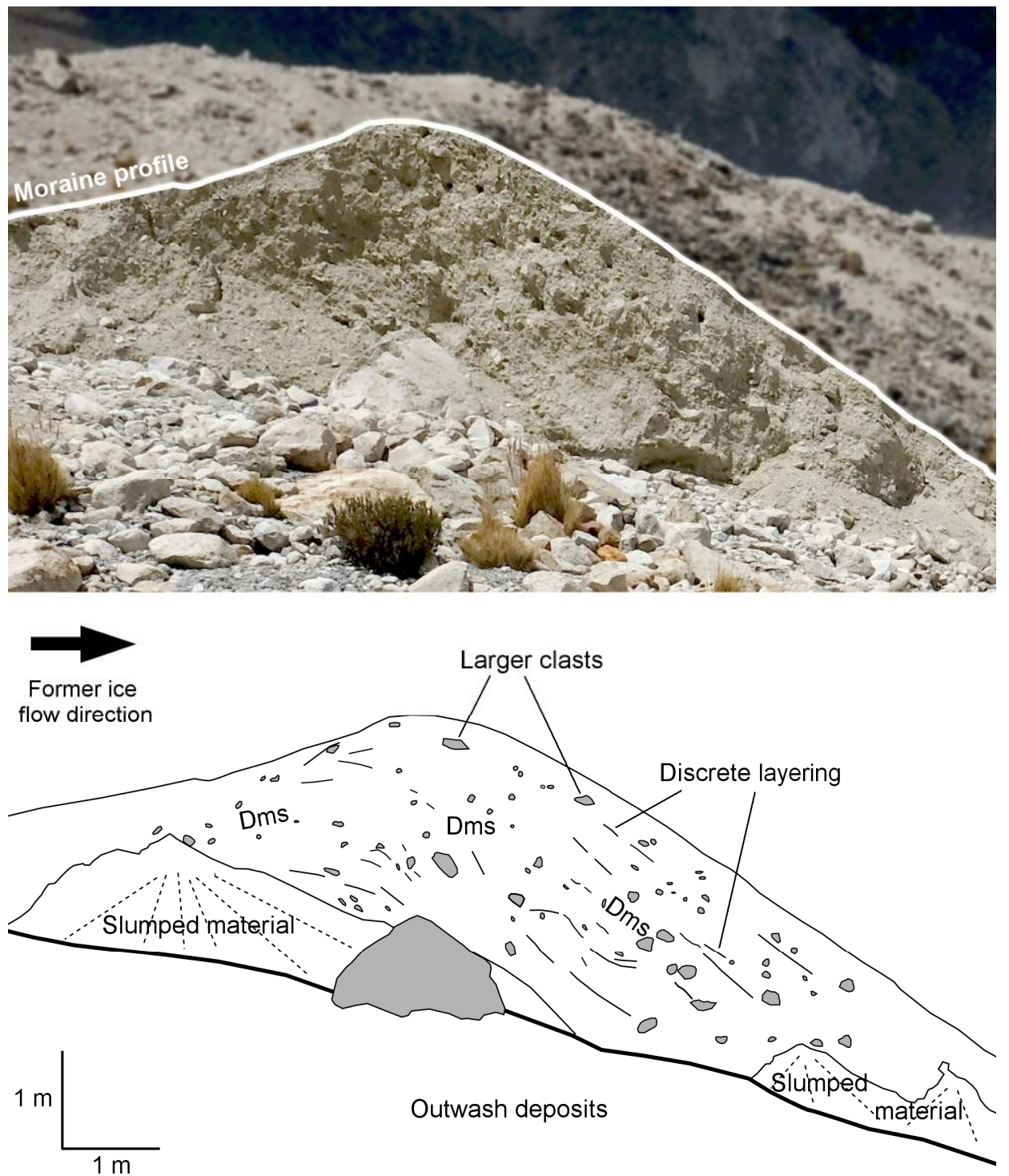

Figure 6 Exposure within an M6 moraine ridge eroded by the western proglacial stream. Dms - stratified matrix-supported diamict. 
within this belt in zones M4-M6, M8-M9 and within the MA moraine ridge suite. The clusters are bounded by crossvalley oriented boulder walls that are extensions of the M8, M9 and MA moraine ridges. The largest boulder wall, composed of $\sim 1 \mathrm{~m}$-wide stacked blocks, is located within the MA suite and is $\sim 2 \mathrm{~m}$ high, $\sim 4 \mathrm{~m}$ wide, and $\sim 80 \mathrm{~m}$ long.

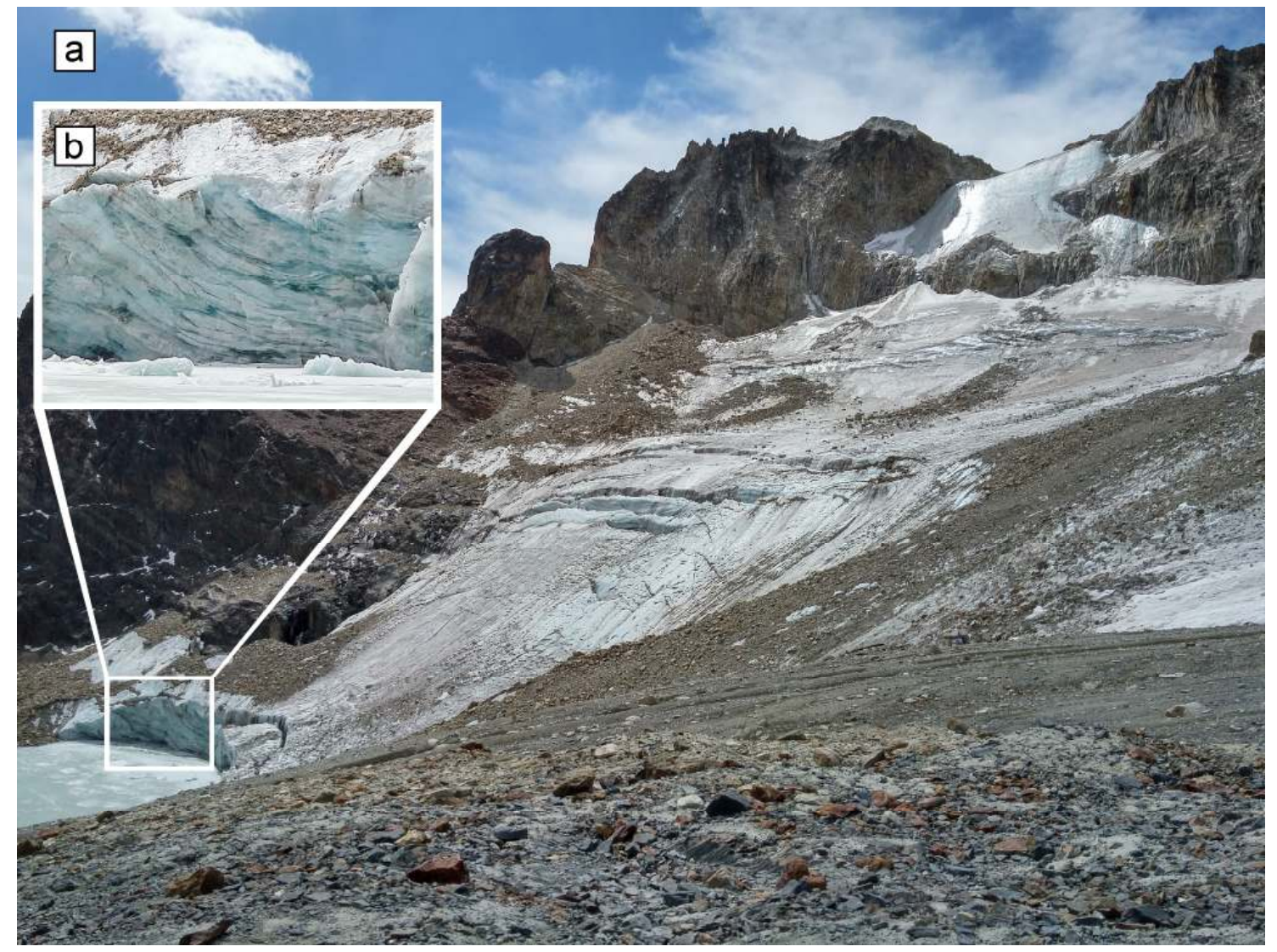

Figure 7 (a) The western part of Charquini Sur in September 2016 with proglacial lake and ice cliff (lower left), transverse crevasses (centre) and thin supraglacial debris cover. (b) Detail of the ice cliff. Note debris-free ice and deformation of the englacial layering.

\section{Sediments and landforms at the glacier margin}

The present-day glacier margin can be classified into two zones of different characteristics. The western zone of the glacier is steep $\left(\sim 30-50^{\circ}\right)$, crevassed, and terminates in a proglacial lake. This lake has expanded from $\sim 350 \mathrm{~m}^{2}$ in 2013 (Fig. 2) to $\sim 6,000 \mathrm{~m}^{2}$ in 2016. Where it meets the lake, the glacier front forms a $\sim 10-15 \mathrm{~m}$-high ice cliff (Fig. 7b). The ice cliff provides an insight into the internal structure of the glacier at the terminus, showing clear evidence for folding and deformation of layering within the ice. The only englacial debris seen within the ice cliff are a few short horizons of material, roughly parallel to the primary stratification layers within the ice, and several individual clasts. The lake is dammed by the glacier margin to the north-east, and rests on gently-inclined bedrock to the south-west. The lake shore is covered by a layer of sediments ranging from mud to boulders, most of which are angular. It was not possible to determine if the lake is underlain by glacier ice.

The central and eastern parts of the glacier surface are moderately sloping $\left(\sim 20^{\circ}\right)$, with very little supraglacial debris cover (Fig. 3e). The only larger crevasses identified in this part of the glacier are bergschrunds adjacent to headwalls. In the central part of the front, where flutings emerge from beneath the glacier, a short section of a subglacial channel provides an insight into the character of glaciofluvial sediment at the glacier bed. The channel fill is a sandy gravel with predominantly angular pebble-sized clasts. Sediment of this type extends from the margin down-valley to the bedrock threshold and forms the main surface sediment cover in this area. The easternmost section of the glacier front sits directly on ice-moulded bedrock with almost no sediment cover.

\section{Glacial processes inferred from the landform-sediment assemblage}

\section{$\underline{\text { Ice-marginal processes }}$}

The 11 moraine ridge suites identified within the Charquini Sur foreland provide a detailed record of overall glacier retreat since the local LIA, represented by the outermost M1 ridges. Three main types of moraines are found within the suites: (1) large latero-frontal ridges that are near-continuous across the foreland (M1, M3, M4, M6); (2) sharp-crested 
lateral moraine ridges that can be correlated to all latero-frontal moraine ridge suites apart from M2 and MB; and (3) groups of small, densely-spaced, parallel ridges (M7, M9, MA, MB) (Fig. 2). Some suites comprise a combination of these moraines, such as M2, which contains both large frontal ridges (1) and groups of small ridges (3). The morphological characteristics of these different types of moraines provide information on the likely ice-marginal processes of moraine formation, and spatial and temporal variations in these processes.

(1) The large, cross-valley latero-frontal moraine ridge suites of M1, M3, M4 and M6 are interpreted to have formed during sustained frontal re-advances and/or periods of margin stability. The following evidence supports this interpretation: (i) these suites contain the largest ridges in the foreland and can be traced into sharp-crested lateral moraines. Larger ridges are consistent with a stable or advancing margin for an extended period of time (i.e. at least several years), allowing more material to be deposited at the margin (e.g. Krüger 1985, 1993; Evans and Twigg, 2002; Evans, 2003b); (ii) some of the suites contain double-crested ridges (M3, M6), indicating glacier re-occupation of a similar position and the formation of an inset ridge (e.g. Benn et al., 2003; Barr and Lovell, 2014); and (iii) flutings are draped on the proximal slope of ridges within the M6 suite, but not overriding the crest, suggesting a genetic link between ridges and flutings (Evans and Twigg, 2002). There is also evidence of erasing and overtopping of older moraines by lateral ridges within the M3, M4 and M6 suites (see (2) below). Rabatel et al. $(2005,2006,2008$ ) also suggested that the M1, M3 and M6 moraine ridge suites were deposited following frontal advances, which can be correlated across several glaciers in the wider region.

(2) The sharp-crested lateral moraines record an overall trend of glacier thinning since the LIA, but also provide evidence consistent with re-advances forming the $M 3, M 4$ and $M 6$ moraine ridge suites. $M 2$ is the only moraine ridge suite at Charquini Sur (other than the youngest MB ridges) that has no identifiable lateral traces. It seems plausible that a sustained frontal re-advance forming the $\mathrm{M} 3$ ridges may have removed or buried any $\mathrm{M} 2$ lateral ridges within both lateral moraines. The M4 and M6 suites are consistent with formation during re-advances based on their partial overtopping of older ridge crests within the western lateral moraine (e.g. Lukas et al., 2012). Not all moraine ridge suites are found on both sides of the valley, indicating that there is within-valley asymmetry (Matthews and Petch, 1982; Benn, 1989). This is particularly clear in the upper part of the foreland, where the MA ridge suite contains multiple ridges within the eastern lateral moraine, but no corresponding ridges in the western moraine (although there are a group at its base) (Fig. 2). Such asymmetry might reflect cross-valley differences in margin activity and/or sediment supply (Matthews and Petch, 1982; Benn, 1989). Although information on the internal structure of the lateral ridges is necessary to determine their genesis (e.g. Lukas et al., 2012), the morphological characteristics (sharpcrested, inset ridges) and predominance of angular and sub-angular clasts are consistent with formation as ice-contact fans at a stable (or re-advancing) margin (e.g. Small, 1983; Benn et al., 2003; Lukas and Sass, 2011).

(3) The small, densely-spaced ridges within the M2, M7, M9, MA and MB moraine ridge suites are interpreted as annual moraines formed by minor seasonal re-advances during overall recession (e.g. Evans and Twigg, 2002; Beedle et al., 2009; Lukas, 2012; Lukas et al., 2012; Chandler et al., 2016a; Wyshnytzky, 2017). Metre-scale readvances of the glacier front during dry-seasons, when melting is low, have been observed within the last 15 years during research visits to conduct mass balance measurements. In 2005, such an advance was observed to form the innermost ridge of the MB suite by the pushing of proglacial sediment at the margin (Fig. 3c). The boulder walls within M8, M9 and MA are also consistent with minor frontal re-advances into a boulder field and the bulldozing of small ridges. Flutings are visible between the MB ridges, similar to the landform pattern observed at active temperate glacier margins in Iceland (Evans and Twigg, 2002; Evans, 2003b; Chandler et al., 2016a,b; Evans et al., 2016, 2017). The presence of annual moraines suggests that, up to 2005 at least, Charquini Sur had a seasonally-oscillating active margin. No ridges were observed to be forming at the glacier margin in 2016, suggesting a change in ice-marginal processes may have occurred in the last decade or so.

The up-valley trend of decreasing moraine size and increasing spacing provide a further indication of temporal changes in glacier margin behaviour. Progressively smaller and less frequent moraine ridges closer to the margin of Charquini Sur might be explained by several different causes. Post-LIA increase of the equilibrium line altitude has resulted in a long-term trend of increasing retreat rates on a centennial scale (Rabatel et al., 2006) and, most likely, decreasing ice velocity at the margin in response to ice thinning. This may have resulted in progressively less pronounced re-advances or stillstands, even during periods of positive mass balance. Superimposed on the mass balance conditions are the notable up-valley reduction in sediment availability and the geometry of the valley bed. Low-relief, gently sloping surfaces with thicker sediment cover, abundant particularly in the lower part of the foreland, are more conducive to the formation and/or preservation of moraine ridge suites (e.g. M1-M4, MA). This contrasts to the steeper, more complex bed topography in the upper part of the foreland, where sediment cover is thin and discontinuous.

The clast morphological characteristics of the diamict found on the surface of the moraines (high RA values, edgerounding, striations etc.) are consistent with material from a mix of subglacial and supraglacial sources. This indicates debris has experienced a combination of both active (subglacial) and passive (supraglacial) transport routes (e.g. Benn, 2004). A down-valley trend of decreasing RA values across successive moraine ridges can be identified in the clast morphology data (Table 3), as well as a generally increasing content of the finest fractions, which are in low abundance close to the ice margin (Table 2). These trends are consistent with a stronger influence of subglacial clast 
modification and erosion the further the material has travelled (particularly as the granitoid lithology originates at the head of the cirque), or, conversely, an increasing contribution of supraglacial material to moraine ridges closer to the active ice margin.

Although moraine morphology can provide some information on genesis of the moraine ridge suites, further investigation of the internal structure of the ridges is necessary in order to provide a greater insight into the exact nature of ice-marginal processes and moraine formation. The only documented exposures of the internal structure of moraines are within minor frontal ridges of the M6 (Fig. 6) and M9 (Fig. 3b) suites. These exposures both show a matrix-supported stratified diamict, with layering uniformly dipping down-valley (away from the ice margin) and some small-scale evidence of folding, indicative of deposition as debris flows (cf. Lawson, 1982; Benn, 1992). This layering is consistent with ridge formation as a terrestrial ice-contact fan (e.g. Lukas, 2005, 2012). Ice-contact fans are formed by supraglacially-sourced debris flows, commonly due to a combination of gravitational and fluvial processes that stack-up against a stable ice margin (Lawson, 1982; Benn, 1992; Krzyszkowski and Zieliński, 2002; Lukas, 2005, 2012; Boston, 2012). Material derived from a mix of sources (e.g. subglacial, supraglacial, glaciofluvial) is common within ice-contact fans, which is consistent with the clast morphology data within the Charquini Sur moraines (Figs 3 and 4). Ice-marginal ridges formed as ice-contact fans can also be subjected to deformation by a subsequent frontal re-advance, creating small-scale deformation structures such as the minor fold within the M6 ridge observed in Figure 6 (e.g. Lukas, 2005, 2012).

\section{Subglacial processes}

The limited supraglacial debris cover on the surface of Charquini Sur has resulted in the subglacial environment being preserved in large parts of the foreland. The physical characteristics of the diamict covering the intermorainic surfaces down-valley of the bedrock threshold are similar to the diamict found on the surface of the moraine ridges, e.g. a sandy-silty matrix-supported diamict with a predominance of angular and sub-angular clasts, some of which are striated and faceted. Based on these characteristics, the distribution of the diamict in relatively flat zones between the moraine ridge suites, and the presence of dense flutings, these areas are interpreted as subglacial sediment cover representing the former bed of the glacier. The formation of this sediment cover is likely to be the result of some combination of the common processes involved in the production of subglacial tills, such as deformation, lodgement, melt-out and ploughing (e.g. Evans et al., 2006b; Evans, 2018), although additional information on sediment stratigraphy is necessary in order to provide further insight into this.

The presence of a fluted subglacial sediment cover indicates that temperate conditions and subglacial deformation of underlying sediment have pervaded at the glacier bed since the LIA (e.g. Paul and Evans, 1974; Boulton, 1976; 1986; Gordon et al., 1992; Evans and Twigg, 2002; Evans, 2003; Benn and Evans, 2010). The area of subglacial sediment, or indeed any sediment cover, is more limited in the zone between the bedrock threshold and the ice margin than throughout the rest of the foreland, with the eastern part of the glacier in particular currently terminating on bedrock. The sediment in this zone comprises mainly sand and angular pebble-sized clasts, which is very similar to the sediments within the subglacial channel emerging from the central part of the glacier front. This implies that subglacial sediments at the ice margin may originate in part from glaciofluvial material. Ice-moulded and striated bedrock is common across the foreland (Fig. 3f), including the large bedrock threshold (Fig. 2), indicating that net erosion, abrasion and ploughing have occurred where sediment is absent at the glacier bed.

\section{Supraglacial processes}

The Charquini Sur glacier surface is largely free of debris. Where there are areas of supraglacial debris, such as on the western side of the glacier surface, the clasts are predominantly very angular and represent the least-modified sediment within the glacier basin. This material reflects sediment input to the glacier surface from talus and snow/rock avalanches originating from the cirque headwall, including occasional large-scale rockfalls, indicated by the presence of a house-sized boulder resting on the glacier surface. In the high-elevation accumulation zone of the glacier, supraglacial debris derived from extraglacial sources is likely to become buried within firn during positive mass balance periods. This debris is then transferred passively in an englacial position before melting out on the glacier surface as frontal supraglacial debris cover that has undergone very little modification (e.g. Fig. 7). Subsequent reworking of this supraglacial debris cover by meltwater action is limited, as the supraglacial channel network is poorly developed. During negative mass balance periods with little or no snow cover, it is possible that some debris from extraglacial sources might fall into crevasses and be routed via a subglacial pathway to the glacier front, or transported passively on the glacier surface. The predominance of granitoid clasts throughout the basin indicates that the cirque headwall is the dominant source of material to the glacier system, with little or no apparent contribution from the valley sides (composed of gneiss and slates), even when the glacier was significantly larger at its LIA maximum position. This may in part be due to the effectiveness of depressions between the lateral moraine ridges in trapping talus from the valley sides (cf. Hewitt, 1993) (Fig. 3d).

Areas of surface sediment cover comprising predominantly angular and very angular debris extend beyond the current glacier in the centre of the foreland. The physical characteristics of this proglacial sediment are very similar to that of supraglacial debris on the current glacier surface, in particular the clast shape and roundness (Figs 4 and 5; Table 3), and therefore we interpret these as supraglacial melt-out deposits. This sediment cover displays an up-valley trend of 
increasing extent, transitioning from the discontinuous discrete linear band extending through the centre of the foreland to widespread cover at the margin (Fig. 2). The linear band is likely to reflect the melt-out of a thin cover of longitudinally-aligned supraglacial debris (e.g. 'Facies 2' in Eyles, 1979), similar to that which can be observed on the western part of the current ice surface (e.g. Fig. 7b). Such arrangements of debris cover on the ice surface can develop as material is linearly redistributed from a point source, such as a rockfall deposit or continuous headwall source, by glacier flow down-valley. The extensive zone of supraglacially-derived debris cover at the margin includes restricted areas of relief inversion and isolated buried ice bodies that are not seen further down-valley. This zone is likely to reflect enhanced melt-out of englacial/supraglacial debris at the glacier front, consistent with increased delivery of debris to the glacier surface due to strongly negative mass balance in recent decades (e.g. Rabatel et al., 2006). The sediment cover at the margin is similar to 'Facies 3 ' in Eyles (1979), described as a mix of supraglacial and glaciofluvial material within ice-cored terrain, common at inactive glacier margins.

\section{Glaciofluvial processes}

Glaciofluvial deposition within the Charquini Sur foreland is primarily focused in the outwash fans in the lowermost zone and along the narrow corridors of the western and eastern meltwater streams. The sediment within the main depositional zones consists of all fractions from mud to boulders, with pebble- and cobble-sized clasts predominant. Clasts sampled from the banks of the active meltwater streams are more-rounded than those sampled from the moraine ridges or subglacial sediments, consistent with the enhanced fluvial modification of clasts (Table 3). The combined glaciofluvial depositional output from the Charquini Sur foreland is represented by the outwash fans beyond the M1 moraine ridge suite, which unsurprisingly show the highest levels of clast modification in the study area (Figs 4 and 5; Table 3). An extended area of glaciofluvial sediment cover is also found emerging from beneath the central part of the modern ice margin.

Despite the common occurrence of potentially erodible fine sediment cover, glaciofluvial erosion is restricted to steeper areas of subglacial deposits, particularly along the eastern lateral moraine and on the banks of both proglacial streams. The latter are covered with dense networks of small dry meltwater channels, typically aligned parallel to neighbouring moraine ridge axes and hence possibly reflecting meltwater drainage guided by the former ice margin.

\section{The glacial landsystem of Charquini Sur}

We have summarised the observed geomorphology and sediment distribution within the Charquini Sur foreland into the first landsystem model for tropical glaciers (Fig. 8). The main components of the landsystem are (i) a series of densely-spaced, large arcuate moraine ridges (in the lower part of the foreland) and smaller moraine ridge suites comprising multiple parallel ridges (in the upper part of the foreland); (ii) lateral moraines consisting of a series of welldefined ridges; (iii) intermorainic zones consisting of fluted subglacial sediments, supraglacial debris melt-out deposits and ice-moulded bedrock; (iv) active meltwater streams, inactive channels, outwash fans and associated zones of glaciofluvial sediments.

\section{Zonation within the landsystem}

The spatial distribution of landforms and sediments within the Charquini Sur landsystem exhibits a clear zonal pattern, which can be divided into three distinct domains based on differences in the inferred dominant processes (Table 4, Fig. 8).

\section{Zone 1: LIA maximum zone}

Zone $1(\sim 4,760-4,780 \mathrm{~m})$ is the lowermost part of the foreland. The terrain is mostly flat and covered by an outwash plain, but also contains the prominent moraine ridge suites M1-M4. Some of the moraine ridges have been reworked by proglacial meltwater action, i.e. partly covered by glaciofluvial sediments and/or locally eroded by stream erosion. Sediment input to this zone is insignificant, since talus from the valley sides is not efficiently transferred to the foreland due to numerous crests in lateral moraines that trap sediment, while glaciofluvial load is low due to low discharge in the proglacial streams. Sediments deposited in this zone are stable and partly vegetated, except for those within the proglacial stream channels. According to the Rabatel et al. (2008) lichenometric chronology, the landform-sediment assemblage in Zone 1 spans a $~ 80$-year period from the local LIA maximum advance in the late- $17^{\text {th }}$ century, when the M1 moraine ridge suite was formed, to the formation of the M4 suite in the mid-18 ${ }^{\text {th }}$ century.

\section{Zone 2: Central foreland}

Zone $2(\sim 4,780-4,930 \mathrm{~m})$ consists of the central part of the foreland and is characterised by a range of glacial landforms. Several generations of cross-valley moraine ridges (M6-MA) are located on the subglacial sediment surface. M6 is the largest moraine ridge suite in the foreland, and represents the most recent significant re-advance of the margin. The other moraine ridges consist of groups of small, parallel ridges in close proximity, and are interpreted as annual moraines. Large groups of flutings and a belt of supraglacial debris are superimposed on subglacial 


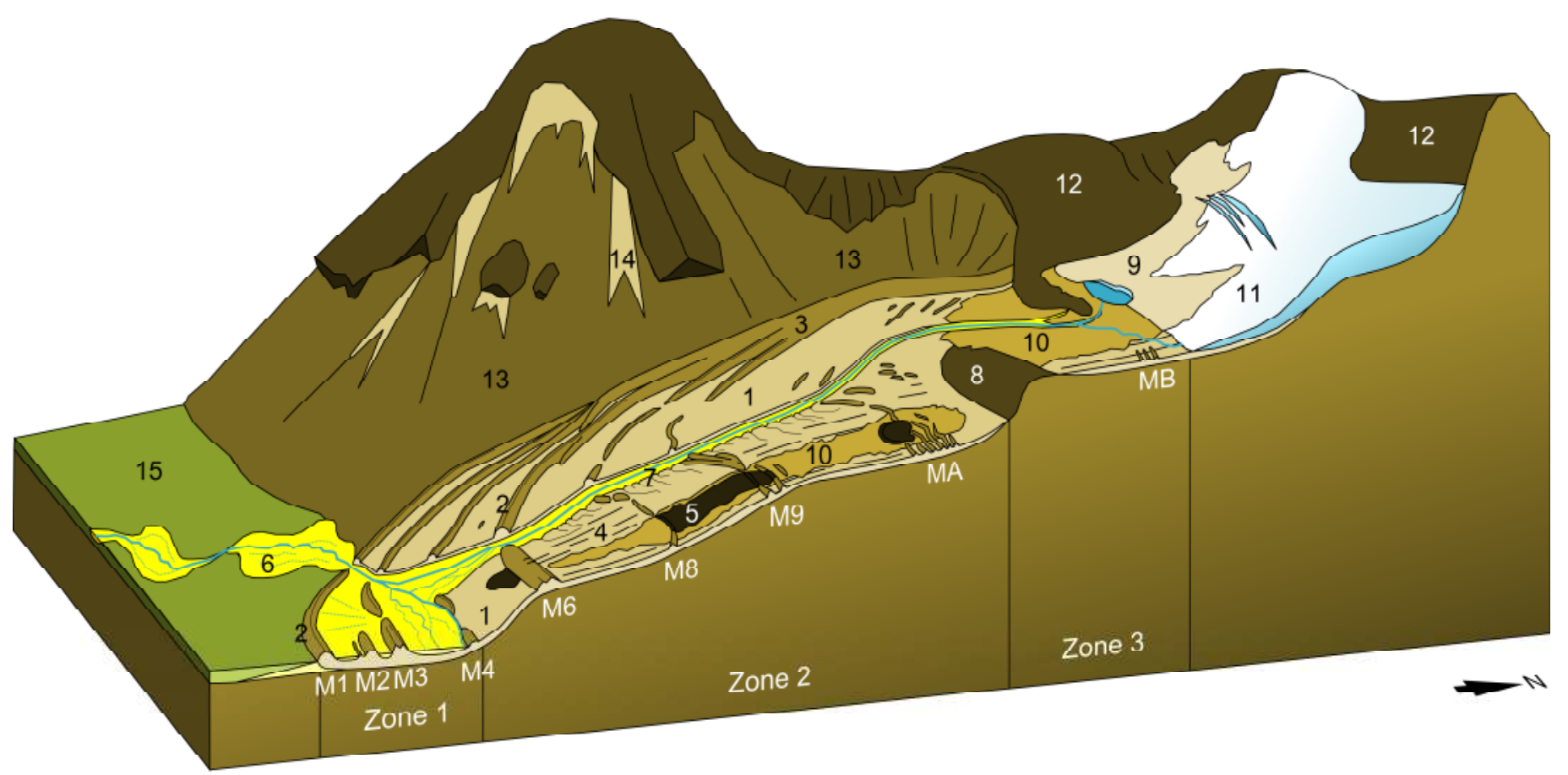

Figure 8 Glacial landsystem of the tropical glacier Charquini Sur. 1 - low-relief subglacial surfaces; 2 - moraine ridges (including both large frontal moraines and small annual moraines); 3 - lateral moraines; 4 - flutings; 5 - boulder fields; 6 - glacifluvial sediments and outwash

plains; 7 - abandoned meltwater channels incised into subglacial sediments; 8 - ice-moulded bedrock; 9 - supraglacial debris; 10 supraglacial melt-out drape; 11 - glacier ice; 12 - rockwalls; 13 - talus; 14 - fine sediment sheets; 15 - soil and vegetation. Symbols M1, M2 etc. refer to successive moraine ridge suites. See the text for reference to Zones 1, 2 and 3.

sediments. This zone also contains numerous relict small meltwater channels incised into the sediment cover, which previously would have routed meltwater away from the receding margin and towards the two main lateral proglacial streams located to the east and west of the foreland. Similar to Zone 1, sediment input and reworking in Zone 2 are low, the latter of which is primarily focused within glaciofluvial corridors. The development of the landform-sediment assemblage in Zone 2 is suggested to have taken place over $\sim 200$ years between the mid- $18^{\text {th }}$ century (formation of M4 moraine ridge suite) and the 1980s based on the Rabatel et al. (2008) lichenometric chronology.

\section{Zone 3: Ice-marginal zone}

The uppermost Zone $3(\sim 4,930-5,000 \mathrm{~m}$ a.s.I.) is located at the present-day glacier front. The middle section of the margin is characterised by flutings on a thin, patchy cover of glaciofluvial sand and gravel and a few minor moraine ridges (MB), most likely annual moraines dating back to the early-2000s. The western part of Zone 3 is dominated by melt-out of supraglacial debris and a developing proglacial lake. To the east the margin overlays ice-moulded bedrock with very little sediment cover. Several exposures of ice-moulded bedrock are found across the entire zone. Scree and snow/rock avalanches from the headwalls provide limited sediment input to the glacier, which typically undergoes minimal modification and is subsequently deposited at the margin as supraglacial melt-out deposits. The exposure of the ice-marginal zone of the landsystem covers approximately the last 30 years.

\section{A tropical cirque glacier landsystem}

The Charquini Sur landsystem (Fig. 8) is, to our knowledge, one of only a few examples of the landform-sediment assemblage at a modern cirque glacier (e.g. Robersen, 2008; Brynjólfsson et al., 2012). However, apart from the comparable size and cirque setting of the glaciers in these examples, there is little similarity between the landsystems. Robersen (2008) mapped proglacial sediments and landforms at Glacier de St. Sorlin in the European Alps and found that the foreland geomorphology was dominated by glaciofluvial activity, which contrasts dramatically with the very low role of water at Charquini Sur. At Tröllaskagi in north-west Iceland, Brynjólfsson et al. (2012) documented crevassesqueeze ridges, poorly-developed flutes and large areas of ice-cored hummocky moraine associated with cirque glacier surges. These landforms can be linked to repeated surges of the glaciers since the local LIA maximum, which is a quite different glacier dynamical setting to that of Charquini Sur.

The Charquini Sur cirque glacier landsystem shares more characteristics with the high-mountain (alpine) clean glacier end-member of the glaciated valley landsystem, as synthesised by Benn et al. (2003). In particular, the well-defined latero-frontal moraine ridges, delimiting inset margin positions, and underdeveloped proglacial glaciofluvial system are common to both. Annual moraines and/or fluted intermorainic zones, typical at lowland clean valley glaciers (e.g. Benn 
Table 4 Zonation of Charquini Sur glacier foreland. For zonal characteristics see text.

\begin{tabular}{|c|c|c|c|}
\hline Zone & Approximate extent & Dominant processes & Characteristic landforms \\
\hline 1 & $\begin{array}{l}\text { Lower foreland } \\
\text { (Moraine ridge } \\
\text { suites M1-M4) }\end{array}$ & $\begin{array}{l}\text { - Formation of prominent moraine ridges } \\
\text { during sustained frontal re-advances } \\
\text { - Glaciofluvial deposition and minor } \\
\text { reworking of moraines }\end{array}$ & $\begin{array}{l}\text { - Outwash plain } \\
\text { - Prominent moraine ridges partly reworked by } \\
\text { proglacial streams in places }\end{array}$ \\
\hline 2 & $\begin{array}{l}\text { Central foreland (up- } \\
\text { valley from M4 } \\
\text { moraine ridge suite } \\
\text { to bedrock } \\
\text { threshold) }\end{array}$ & $\begin{array}{l}\text { - Formation of moraine ridges decreases } \\
\text { up-valley } \\
\text { - Subglacial deposition and sediment } \\
\text { deformation } \\
\text { - Supraglacial deposition }\end{array}$ & $\begin{array}{l}\text { - Moraine ridges generally decreasing in size towards } \\
\text { the glacier } \\
\text { - Fluted subglacial sediments on gentle surfaces } \\
\text { - Meltwater channels incised into sediment cover on } \\
\text { more inclined surfaces } \\
\text { - Longitudinal belt of draped supraglacial debris with } \\
\text { boulder fields }\end{array}$ \\
\hline 3 & $\begin{array}{l}\text { Upper foreland } \\
\text { (bedrock threshold } \\
\text { to glacier front) }\end{array}$ & $\begin{array}{l}\text { - Supraglacial deposition (western margin) } \\
\text { - Subglacial deposition (central margin) } \\
\text { - Net erosion of bedrock (eastern margin) }\end{array}$ & $\begin{array}{l}\text { - Supraglacial debris drape with some buried ice } \\
\text { - Thin fluted glaciofluvial sediment cover } \\
\text { - Ice-moulded bedrock }\end{array}$ \\
\hline
\end{tabular}

and Evans, 1998), active-temperate glacier margins (e.g. Evans and Twigg, 2002; Evans, 2003b; Bradwell, 2004; Chandler et al., 2016b), and plateau-icefield outlet glaciers (e.g. Evans et al., 2006, 2016; Evans 2010), have also been reported from other high-mountain, clean glaciers (e.g. in the European Alps; Lukas, 2012). The main distinctions of the Charquini Sur landsystem, other than its smaller cirque glacier size compared to the alpine valley glacier examples, is the excellent preservation of ice-marginal and subglacial landforms despite having been exposed to subaerial processes for hundreds-of-years (cf. Rabatel et al., 2005, 2008). The main factors responsible for this high degree of preservation, and the overall formation of the landsystem, are discussed below.

Benn et al. (2003) identified three main controls on landform formation in glaciated valleys: topography, debris supply to the glacier surface, and efficiency of sediment transport from the glacier to the foreland. Topography and debris supply to the glacier surface also play an important role in the tropical cirque glacier setting of Charquini Sur, in addition to temporal changes in margin activity. The influence of topography on landform distribution is most apparent in Zones 1 and 2 of the foreland. In Zone 1, coalescent outwash fans have developed on low-gradient terrain, with no other landforms preserved aside from large moraine ridges. Within the steeper terrain of Zone 2, the absence of expansive glaciofluvial deposition, in addition to the lack of large bedrock protuberances, has promoted the formation and preservation of small moraine ridges and flutings. Debris supply to the glacier surface, and supraglacial transport thereafter, are relatively low at Charquini Sur. The likely reasons for this include rather poor debris yields from the source headwall, due to its lithology (relatively resistant igneous rock) and limited spatial extent, as well as efficient trapping of debris from the valley sides in the lateral moraine troughs. glaciofluvialTemporal changes in margin activity are responsible for spatial variations in moraine morphology and formation within the Charquini Sur landsystem. Large, cross-valley moraine ridge suites in Zone 1 and lower Zone 2 represent sustained periods of frontal advance or stability. Groups of annual moraines in upper Zone 2 indicate seasonal (dry season) margin fluctuations during overall recession. In zone 3, the general scarcity of ridges close to the current margin (aside from MB ridges) and the development of areas of supraglacial melt-out deposits with buried ice suggest the margin has become inactive within the last decade.

Post-formation, the low role of water in the environment has a significant control on the excellent preservation of the landforms, which can be attributed to a number of factors. (i) The precipitation regime is characterized by relatively low annual totals ( $400-800 \mathrm{~mm}$ ), infrequent rain events, and limited snow cover duration below 5,000 $\mathrm{m}$ (Francou and Bertran, 1997; Wagnon et al., 2001; Sicart et al., 2005). This reflects the location of Charquini Sur in an outer-tropical high-mountain environment. (ii) Water evaporates rapidly from the surface due to high solar radiation. The overall paucity of available water in the landscape means that surficial freeze-thaw cycles, although frequent, are an inefficient weathering mechanism (Francou and Bertran, 1997; Francou et al., 2001). (iii) Buried ice is largely absent across the foreland, reflecting low supraglacial debris cover on the glacier surface and ice-marginal moraine formation processes (e.g. push/squeeze and ice-contact fans; Price 1970; Boulton 1986) that incorporate little or no glacier ice. The melting of buried ice typically leads to water saturation of sediments and the associated landform instability, in contrast to the stable moraine ridge suites and intermorainic surfaces at Charquini Sur. (iv) The proglacial drainage architecture is confined to the narrow corridors of the eastern and western streams throughout most of the foreland, and thus large areas have not been subject to fluvial reworking or erosion. The coalescent outwash fans in the flattest part of the foreland between M1 and M6 appear to have had little impact on censoring of the moraine record, aside from partly burying the base of some ridges. Together, this suggests that the long-term preservation potential of the landsystem is high. Such long-term preservation is seen in other arid mountain regions outside of South America, such as in Mongolia, Central Asia, where well-defined inset recessional moraine ridges of Last Glacial Maximum (LGM) and pre-LGM age are found in a number of glaciated valleys (Batbaatar et al., 2018). 
The modern mass balance of glaciers in the Cordillera Real is mostly negative with high-elevation ELAs, attributed to regional air temperature increases of $0.10^{\circ} \mathrm{C}$ decade $^{-1}$ in the last 70 years (Rabatel et al., 2013). This has caused rapid melting of local glaciers and complete decay of some lower-elevation ice masses $(<5,300 \mathrm{~m})$ (Ramirez et al., 2001; Soruco et al., 2009; Cook et al., 2015). Mass balance monitoring of Charquini Sur for the period 2003-2013 showed its mean ELA and mass balance have been $\sim 5,200 \mathrm{~m}$ and $-1 \mathrm{~m}$ w.e. $\mathrm{yr}^{-1}$, respectively (WGMS, 2016). The mean ice thickness across the glacier is $\sim 20 \mathrm{~m}$ (A. Rabatel, unpublished radar data), and thus, assuming a similar mass balance in upcoming decades, the glacier is expected to nearly disappear by the mid- $21^{\text {st }}$ century (Rabatel et., 2006). This glacier recession is likely to extend Zone 3 up to the cirque headwalls. As the glacier front continues to thin, the decreasing activity of the margin will eventually be insufficient to produce annual moraines (the most likely origin of the MB ridges); this is probably already the case as no ridges have formed since $\sim 2005$. The decrease in activity leading to ice stagnation will also result in the cessation of the formation of flutings, although those that have already formed at the bed will continue to be exposed by frontal recession.

The glacier surface is largely free of supraglacial debris at present and there is a general absence of buried ice across the majority of the foreland, suggesting that the development of ice-cored topography is limited at Charquini Sur. However, there are some small areas of buried ice within Zone 3 close to the glacier margin. As the glacier thins, any sediment within the ice will be released, potentially forming a thicker supraglacial cover at the front than at present. Depending on the englacial sediment load, over time this could develop into an enlarged ice-marginal zone of hummocky ice-cored topography or 'controlled' moraine (see Evans, 2009). Areas of thicker debris cover insulate the underlying glacier ice whilst adjacent areas of thinner debris cover continue to lower The formation of controlled moraine is common in high-latitude glacial environments (e.g. Etzelmüller et al., 1996; Krüger and Kjær, 2000; Kjær and Krüger, 2001; Lukas et al., 2005; Evans, 2009; Ewertowski et al., 2012).

The expansion of the proglacial lake as the front recedes is dependent on the local bed topography at the western margin, such as the presence of an overdeepened section extending up-glacier. If the bedrock geometry permits the lake to eventually disconnect from the margin, it is likely to persist in the landscape and continue to be fed by meltwater from high-elevation snow and ice. Surrounding the cirque lake, the uppermost parts of the de-iced foreland will eventually comprise areas of ice-moulded bedrock with coarse sediment drapes of supraglacial and glaciofluvial origin.

\section{Palaeoglaciological implications}

The characteristics of the Charquini Sur landsystem provide a useful reference point for reconstructing deglaciating and deglaciated arid and semi-arid high-mountain environments, both in the tropics and, potentially, at some higher latitudes (e.g. Batbaatar et al., 2018). In particular, the landsystem provides further evidence for a link between landform characteristics, such as well-defined suites of inset moraine ridges and preservation of the subglacial landform-sediment assemblage, and specific glaciological conditions, namely limited supraglacial debris cover and low and ineffective glaciofluvial transport. Our investigation also highlights the variability in moraine morphology and sediment distribution even within a relatively small glaciated cirque, inferred to reflect changes in margin activity over time. This has important implications for using moraine records of small glaciers in similar environments to reconstruct ELAs and, by extension, palaeoclimate conditions (e.g. Kerschner and Ivy-Ochs, 2008; Kirkbride and Winkler, 2012). For example, some of the moraine ridges at Charquini Sur formed as annual moraines during overall recession (i.e. when the glacier was out-of-balance with climate), and therefore it follows that not all moraines in the tropical Andes are suitable for reconstructions of past ELAs using methods that assume steady-state conditions.

\section{Conclusions}

In this study, we present a detailed geomorphological assessment of Charquini Sur, a cirque glacier in the tropical Bolivian Andes, in order to (1) characterise the landform-sediment assemblage of a tropical glacier, and (2) provide an insight into its behaviour since the Little Ice Age (LIA). Our mapping at 1:4,000 scale reveals a succession of wellpreserved arcuate moraine ridge suites, with flutings and a thin cover of subglacial, supraglacial and glaciofluvial sediments in the intervening zones. The moraine ridge suites record an overall pattern of recession over a distance of $\sim 1 \mathrm{~km}$ since the local LIA maximum. In places, a number of morphological features, such as removal and overtopping of older ridges by younger ridges, suggests that some of the moraine ridge suites formed during re-advances. Denser groups of smaller ridges, predominantly located in the upper part of the foreland, are interpreted as annual moraines. There is a general up-valley trend of decreasing moraine ridge size, and, apart from one small area of minor ridges, an absence of moraine ridges close to the present-day ice margin. Together, this implies that the ice margin has become less active over time. Additional information on moraine formation (e.g. internal structure) would help to test this. We synthesise the landform-sediment assemblage into the first landsystem model for a tropical cirque glacier. We hope that this work will serve as a useful reference for further studies on the evolution of tropical glaciers and as an analogue for palaeoglaciological reconstructions in high-mountain environments. 


\section{Acknowledgements}

The study is an outcome of the exploration and research project "GEOpraktyki", an initiative by the Student Research Circle of Geographers of Adam Mickiewicz University (WE, ŁG, TK, BL, MM, DP, JP, TS, MS and AW). The project was generously funded by the rector of AMU and the dean of the Faculty of Geographical and Geological Sciences AMU. Financial support by the counties of Mogilno and Pleszew and the communes of Rokietnica and Rydzyna are sincerely acknowledged. Technical support by private companies GOCLEVER, ISIC, Taternik, AGROMIX, Spomasz, 4LAN.eu, Drukarnia Swarzędzka and Nowa Czytelnia Pub\&Café is also greatly appreciated. JM was funded by the Faculty of Geographical and Geological Sciences AMU. AR acquired the Pléiades orthoimage of the Charquini area within the CNES Isis-Pléiades program FC-18473. We thank Alvaro Soruco for his advice during expedition preparations. Feedback provided by the Editors, an anonymous reviewer, Ben Chandler and David Evans greatly helped to improve the manuscript and is sincerely appreciated.

\section{Contribution statement}

JM designed the study, lead the remote mapping, fieldwork and final map production, interpreted the data and wrote the manuscript. HL interpreted the data and co-wrote the manuscript. WE, ŁG, TK, BL, MM, DP, JP, TS, MS and AW took part in the fieldwork and contributed to the final map production. AR provided remote sensing data and contributed to interpretations.

\section{References}

Alcalá-Reygosa J, Palacios D, Zamorano Orozco JJ. 2016. Geomorphology of the Ampato volcanic complex (Southern Peru). Journal of Maps 12 (5): 1160-1169. DOI: 10.1080/17445647.2016.1142479.

Arendt A, Bliss A, Bolch T, Cogley JG, Gardner AS, Hagen J-O, Hock R, Huss M, Kaser G, Kienholz C, Pfeffer WT, Moholdt G, Paul F, Radić V et al. 2015. Randolph Glacier Inventory - A Dataset of Global Glacier Outlines: Version 5.0. Global Land Ice Measurements from Space, Boulder Colorado, USA. Digital Media (access: July $\left.26^{\text {th }} 2017\right)$.

Barr ID, Lovell H. 2014. A review of topographic controls on moraine distribution. Geomorphology 226: 44-64.

Batbaatar J, Gillespie AR, Fink D, Matmon A, Fujioka T. 2018. Asynchronous glaciations in arid continental climate. Quaternary Science Reviews 182: 1-19.

Beedle MJ, Menounos B, Luckman BH, Wheate R. 2009. Annual push moraines as climate proxy. Geophysical Research Letters 36, L20501.

Bendle JM, Glasser NF. 2012. Palaeoclimatic reconstruction from lateglacial (younger dryas chronozone) cirque glaciers in snowdonia, north wales. Proceedings of the Geologists' Association 123(1): 130-145.

Benn DI.1989. Debris transport by Loch Lomond Readvance glaciers in Northern Scotland: Basin form and the within-valley asymmetry of lateral moraines. Journal of Quaternary Science 4(3): 243-254.

Benn DI. 1992. The genesis and significance of 'hummocky moraine': evidence from the Isle of Skye, Scotland. Quaternary Science Reviews 11(7-8): 781-799.

Benn DI. 2004. Clast morphology. In A Practical Guide to the Study of Glacial Sediments, Evans DJA, Benn DI (eds). Arnold: London; 78-92.

Benn DI, Owen LA. 2002. Himalayan glacial sedimentary environments: a framework for reconstructing and dating the former extent of glaciers in high mountains. Quaternary International 97-98: 3-25.

Benn DI, Evans DJA. 1998. Glaciers and glaciation (1 $1^{\text {st }}$ ed.). Arnold: London.

Benn DI, Evans DJA. 2010. Glaciers and glaciation ( $2^{\text {nd }}$ ed.). Hodder Education: London.

Benn DI, Kirkbride MP, Owen LA, Brazier V. 2003. Glaciated valley landsystems. In Glacial landsystems, Evans DJA (Ed). Arnold: London; 372-406.

Bickerdike HL, Ó Cofaigh C, Evans DJA, Stokes CR. 2017. Glacial landsystems, retreat dynamics and controls on Loch Lomond Stadial (Younger Dryas) glaciation in Britain. Boreas, in press.

Bickerton RW, Matthews A. 1993. 'Little Ice Age' variations of outlet glaciers from the Jostedalsbreen ice-cap, southern Norway: a regional lichenometric-dating study of ice-marginal moraine sequences and their climatic significance. Journal of Quaternary Science 8: 45-66. DOI:10.1002/jqs.3390080105.

Blott SJ, Pye K. 2001. GRADISTAT: a grain size distribution and statistics package for the analysis of unconsolidated sediments. Earth Surface Processes and Landforms 26(11): 1237-1248.

Bolch T, Kulkarni A, Kääb A, Huggel C, Paul F, Cogley JG, ... Bajracharya S. 2012. The state and fate of Himalayan glaciers. Science 336(6079): 310-314.

Boston CM. 2012. A Lateglacial plateau icefield in the Monadhliath Mountains, Scotland: reconstruction, dynamics and palaeoclimatic implications. PhD thesis, Queen Mary University of London, $295 \mathrm{pp}$. Available at: https://qmro.qmul.ac.uk/xmlui/handle/123456789/8314 
Boulton GS. 1976. The origin of glacially fluted surfaces-observations and theory. Journal of Glaciology 17(76): 287309.

Boulton GS. 1986. Push-moraines and glacier-contact fans in marine and terrestrial environments. Sedimentology 33(5): 677-698.

Bradley RS, Vuille M, Diaz HF, Vergara W. 2006. Threats to water supplies in the tropical Andes. Science 312(5781): 1755-1756.

Bradwell T. 2004. Annual moraines and summer temperatures at Lambatungnajökull, Iceland. Arctic, Antarctic and Alpine Research, 36(4): 502-508.

Bradwell T, Dugmore A, Sugden D. 2006. The Little Ice Age glacier maximum in Iceland and the North Atlantic Oscillation: evidence from Lambatungnajökull, southeast Iceland. Boreas 35: 61-80.

Brynjólfsson S, Ingólfsson Ó, Schomacker A. 2012. Surge fingerprinting of cirque glaciers at the Tröllaskagi peninsula, North Iceland. Jökull 62, 151-166.

Brynjólfsson S, Schomacker A, Ingólfsson Ó. 2014. Geomorphology and the Little Ice Age extent of the Drangajökull ice cap, NW Iceland, with focus on its three surge-type outlets. Geomorphology 213: 292-304. DOI: 10.1016/j.geomorph.2014.01.019.

Brynjólfsson S, Schomacker A, Guðmundsdóttir ER, Ingólfsson Ó. 2015. A 300-year surge history of the Drangajökull ice cap, northwest Iceland, and its maximum during the 'Little Ice Age'. The Holocene 25 (7): 1076 - 1092. DOI:10.1177/0959683615576232.

Burki V, Larsen E, Fredin O, Nesje A. 2009. Glacial remobilization cycles as revealed by lateral moraine sediment, Bødalsbreen glacier foreland, western Norway. The Holocene 19 (3): 415-426.

Chandler BM, Lukas S. 2017. Reconstruction of Loch Lomond Stadial (Younger Dryas) glaciers on Ben More Coigach, north-west Scotland, and implications for reconstructing palaeoclimate using small ice masses. Journal of Quaternary Science 32(4): 475-492.

Chandler BMP, Evans DJA, Roberts DH. 2016a. Characteristics of recessional moraines at a temperate glacier in SE Iceland: Insights into patterns, rates and drivers of glacier retreat. Quaternary Science Reviews 135: 171-205.

Chandler BMP, Evans DJA, Roberts DH, Ewertowski MW, Clayton Al. 2016b. Glacial geomorphology of the Skálafellsjökull foreland, Iceland: A case study of 'annual' moraines. Journal of Maps 12(5): 904-916.

Cook S, Kougkoulos I, Edwards LA, Dortch J, Hoffman D. 2016. Glacier change and glacial lake outburst flood risk in the Bolivian Andes. The Cryosphere 10: 2399-2413. DOI: 10.5194/tc-10-2399-2016

Darvill CM, Stokes CR, Bentley MJ, Evans DJ, Lovell H. 2017. Dynamics of former ice lobes of the southernmost Patagonian Ice Sheet based on a glacial landsystems approach. Journal of Quaternary Science 32(6): 857-876. DOI: $10.1002 /$ jqs.2890

Davis PT, Menounos B, Osborn G. 2009. Holocene and latest Pleistocene alpine glacier fluctuations: a global perspective. Quaternary Science Reviews 28(21): 2021-2033.

Deline P, Orombelli G. 2005. Glacier fluctuations in the western Alps during the Neoglacial, as indicated by the Miage morainic amphitheatre (Mont Blanc massif, Italy). Boreas 34(4): 456-467.

Etzelmüller B, Hagen JO, Vatne G, Ødegård RS, Sollid JL. 1996. Glacier debris accumulation and sediment deformation influenced by permafrost: examples from Svalbard. Annals of Glaciology 22: 53-62.

Evans DJA. 2003a. Glacial landsystems. Arnold: London.

Evans DJA. 2003b. Ice-marginal terrestrial landsystems: Active temperate glacier margins. In Glacial landsystems, Evans DJA. (Ed.). Arnold: London; 12-37.

Evans DJA. 2010. Controlled moraine development and debris transport pathways in polythermal plateau icefields: examples from Tungnafellsjökull, Iceland. Earth Surface Processes and Landforms 35(12): 1430-1444.

Evans DJA. 2018. Till: A glacial process sedimentology. Chichester: John Wiley \& Sons.

Evans DJA, Rea BR. 1999. Geomorphology and sedimentology of surging glaciers: a land-systems approach. Annals of Glaciology 28(1): 75-82.

Evans DJA, Twigg DR. 2002. The active temperate glacial landsystem: a model based on Breiðamerkurjökull and Fjallsjökull, Iceland. Quaternary science reviews 21 (20): 2143-2177.

Evans DJA, Benn DI. 2004. Facies description and the logging of sedimentary exposures. In A practical guide to the study of glacial sediments, Evans DJA, Benn DI (eds). Arnold: London; 11-51.

Evans DJA, Lemmen DS, Rea BR. 1999. Glacial landsystems of the southwest Laurentide Ice Sheet: modern Icelandic analogues. Journal of Quaternary Science 14(7): 673-691.

Evans DJA, Twigg DR, Shand M. 2006a. Surficial geology and geomorphology of the pórisjökull plateau icefield, westcentral Iceland. Journal of Maps 2(1): 17-29.

Evans DJA, Phillips ER, Hiemstra JF, Auton CA. 2006b. Subglacial till: formation, sedimentary characteristics and classification. Earth-Science Reviews 78(1): 115-176.

Evans DJA, Ewertowski M, Orton C. 2016a. Fláajökull (north lobe), Iceland: active temperate piedmont lobe glacial landsystem. Journal of Maps 12(5): 777-789.

Evans DJA, Ewertowski MW, Orton C, Harris C, Guð̌mundsson S. 2016b. Snæfellsjökull volcano-centred ice cap landsystem, West Iceland. Journal of Maps 12(5): 1128-1137.

Evans DJA, Ewertowski MW, Orton C. 2017. Skaftafellsjökull, Iceland: glacial geomorphology recording glacier recession since the Little Ice Age. Journal of Maps 13: 358-368.

Ewertowski MW, Kasprzak L, Szuman I, Tomczyk AM. 2012. Controlled, ice-cored moraines: sediments and geomorphology. An example from Ragnarbreen, Svalbard. Zeitschrift für Geomorphologie, 56(1), 53-74. 
Ewertowski MW, Evans DJA, Roberts DH, Tomczyk AM. 2016. Glacial geomorphology of the terrestrial margins of the tidewater glacier, Nordenskiöldbreen, Svalbard. Journal of Maps 12: 476-487. DOI: 10.1080/17445647.2016.1192329

Eyles N. 1979. Facies of supraglacial sedimentation on Icelandic and Alpine temperate glaciers. Canadian Journal of Earth Sciences 16(7): 1341-1361.

Fitzsimons SJ. 2003. Ice-marginal terrestrial landsystems: polar continental glacier margins. In Glacial landsystems, Evans DJA. (Ed.). Arnold: London; 89-110.

Forget M-E, Thouret J-C, Kuentz A, Fontugne M. 2008. Héritages glaciaires, périglaciaires et évolution récente: le cas du Nevado Coropuna (Andes centrales, sud du Pérou. Géomorphologie: relief, processus, environnement 14(2): 113-132.

Francou B, Bertran P. 1997. A multivariate analysis of clast displacement rates on stone-banked sheets, Cordillera Real, Bolivia. Permafrost and Periglacial Processes 8: 371-382.

Francou B, Le Méhauté N, Jomelli V. 2001. Factors controlling spacing distances of sorted stripes in a low-latitude, alpine environment (Cordillera Real, $16^{\circ} \mathrm{S}$, Bolivia). Permafrost and Periglacial Processes 12(4): 367-377. DOI: 10.1002/ppp.398

Glasser NF, Hambrey MJ. 2002. Sedimentary facies and landform genesis at a temperate outlet glacier: Soler Glacier, North Patagonian Icefield. Sedimentology 49(1): 43-64.

Glasser NF, Hambrey MJ. 2003. Ice-marginal terrestrial landsystems: Svalbard polythermal glaciers. In Glacial Landsystems, Evans DJA (ed). Arnold, London; 65-88.

Glasser NF, Jansson KN, Harrison S, Rivera A. 2005. Geomorphological evidence for variations of the North Patagonian Icefield during the Holocene. Geomorphology 71(3): 263-277.

Glasser NF, Clemmens S, Schnabel C, Fenton CR, Mchargue L. 2009. Tropical glacier fluctuations in the Cordillera Blanca, Peru between 12.5 and 7.6 ka from cosmogenic 10Be dating. Quaternary Science Reviews 28: 34483458. DOI: 10.1016/j.quascirev.2009.10.006

Golledge NR. 2007. An ice cap landsystem for palaeoglaciological reconstructions: characterizing the Younger Dryas in western Scotland. Quaternary Science Reviews 26: 213-229.

Gordon JE, Whalley WB, Gellatly AF, Vere DM. 1992. The formation of glacial flutes: assessment of models with evidence from Lyngsdalen, North Norway. Quaternary Science Reviews 11(7-8): 709-731.

Graham AG, Larter RD, Gohl K, Hillenbrand CD, Smith JA, Kuhn G. 2009. Bedform signature of a West Antarctic palaeo-ice stream reveals a multi-temporal record of flow and substrate control. Quaternary Science Reviews 28(25): 2774-2793.

Hambrey MJ, Glasser NF. 2012. Discriminating glacier thermal and dynamic regimes in the sedimentary record. Sedimentary Geology 251-252: 1-33. DOI: 10.1016/j.sedgeo.2012.01.008

Hannesdóttir H, Björnsson H, Pálsson F, Aðalgeirsdóttir G, Guðmundsson S. 2015. Variations of southeast Vatnajökull ice cap (Iceland) 1650-1900 and reconstruction of the glacier surface geometry at the Little Ice Age maximum. Geografiska Annaler: Series A, Physical Geography 97(2): 237-264.

Heine K. 2011. Late Quaternary Glaciations in Bolivia: Comments on Some New Approaches to Dating Morainic Sequences. In Quaternary glaciations - extent and chronology: a closer look, Ehlers J, Gibbard PL, Hughes PD (eds). Elsevier, Amsterdam; 757-772.

Hewitt K. 1993. Altitudinal organisation of Karakoram geomorphic processes and depositional environments. In Himalaya to the sea, Shroder JF. (Ed.) Routledge: London; 159-183.

Ingólfsson Ó, Benediktsson ÍÖ, Schomacker A, Kjær KH, Brynjólfsson S, Jonsson SA, Korsgaard NJ \& Johnson MD. 2016. Glacial geological studies of surge-type glaciers in Iceland - Research status and future challenges. Earth-Science Reviews 152: 37-69. DOI: 10.1016/j.earscirev.2015.11.008

IPCC 2014. Climate Change 2014: Synthesis Report; IPCC Fifth Assessment Synthesis Report. Geneva: IPCC: Geneva.

Jomelli V, Favier V, Rabatel A, Brunstein D, Hoffmann G, Francou B. 2009. Fluctuations of glaciers in the tropical Andes over the last millennium and palaeoclimatic implications: A review. Palaeogeography, Palaeoclimatology, Palaeoecology 281(3): 269-282.

Jomelli V, Khodri M, Favier V, Brunstein D, Ledru MP, Wagnon P, Blard PH, Sicart JE, Braucher R, Grancher D, Bourlès DL, Bracannot P, Vuille M. 2011. Irregular tropical glacier retreat over the Holocene epoch driven by progressive warming. Nature 474: 196-199. DOI: 10.1038/nature10150

Jordan E. 1991 Die Gletscher der bolivianischen Anden: eine photogrammetrisch-kartographische Bestandsaufnahme der Gletscher Boliviens als Grundlage für klimatische Deutungen und Potential für die wirtschaftliche Nutzung. Stuttgart, Franz Steiner Verlag. (Erdwissenschaftliche Forschung 23.).

Kerschner H, Ivy-Ochs S. 2008. Palaeoclimate from glaciers: Examples from the Eastern Alps during the Alpine Lateglacial and early Holocene. Global and Planetary Change 60(1-2): 58-71.

Kirkbride MP. 2000. Ice-marginal geomorphology and Holocene expansion of debris-covered Tasman Glacier, New Zealand. Debris-covered glaciers, Nakawo M, Raymond C, Fountain A. (Eds) IAHS Publication 264: $211-217$.

Kirkbride MP. Winkler S. 2012. Correlation of Late Quaternary moraines: impact of climate variability, glacier response, and chronological resolution. Quaternary Science Reviews 46: 1-29.

Kjær HH, Korsgaard NJ, Schomacker A. 2008. Impact of multiple glacier surges - a geomorphological map from Brúarjökull, East Iceland. Journal of Maps v2008: 5-20. DOI:10.4113/jom.2008.91.

Kjær KH, Krüger J. 2001. The final phase of dead-ice moraine development: processes and sediment architecture, Kötlujökull, Iceland. Sedimentology 48: 935-952. 
Krüger J. 1985. Formation of a push moraine at the margin of Höfdabrekkujökull, South Iceland. Geografiska Annaler: Series A, Physical Geography 67(3-4): 199-212.

Krüger J. 1993. Moraine-ridge formation along a stationary ice front in Iceland. Boreas 22(2): 101-109.

Krüger J. 1994. Glacial processes, sediments, landforms, and stratigraphy in the terminus region of Mýrdalsjökull, Iceland. Folia Geographica Danica 21, 1-233.

Krüger J, Kjær KH. 2000. De-icing progression of ice-cored moraines in a humid, sub-polar climate, Kotlujökull, Iceland. The Holocene 48: 935-952.

Krzyszkowski D, Zieliński T. 2002. The Pleistocene end moraine fans: controls on their sedimentation and location. Sedimentary Geology 149(1): 73-92.

Lawson DE. 1982. Mobilization, movement and deposition of active subaerial sediment flows, Matanuska Glacier, Alaska. The Journal of Geology 90(3): 279-300.

Lea JM, Mair DW, Nick FM, Rea BR, Weidick A, Kjaer KH, Schofield JE. 2014. Terminus-driven retreat of a major southwest Greenland tidewater glacier during the early 19th century: insights from glacier reconstructions and numerical modelling. Journal of Glaciology 60(220): 333-344.

Lukas S. 2005. A test of the englacial thrusting hypothesis of 'hummocky'moraine formation: case studies from the northwest Highlands, Scotland. Boreas, 34(3), 287-307.

Lukas S. 2012. Processes of annual moraine formation at a temperate alpine valley glacier: insights into glacier dynamics and climatic controls. Boreas, 41(3), 463-480.

Lukas S, Sass O. 2011. The formation of Alpine lateral moraines inferred from sedimentology and radar reflection patterns: a case study from Gornergletscher, Switzerland. In Ice-Marginal and Periglacial Processes and Sediments, Martini IP, French HM, Pérez Alberti A. (eds). Geological Society: London; 77-92. DOI: 10.1144/SP354.5.

Lukas S, Nicholson LI, Ross FH, Humlum O. 2005. Formation, meltout processes and landscape alteration of highArctic ice-cored moraines-Examples from Nordenskiold Land, central Spitsbergen. Polar Geography 29(3): 157-187.

Lukas S, Graf A, Coray S, Schlüchter C. 2012. Genesis, stability and preservation potential of large lateral moraines of Alpine valley glaciers-towards a unifying theory based on Findelengletscher, Switzerland. Quaternary Science Reviews 38: 27-48.

Lukas S, Benn D I, Boston C M, Brook M, Coray S, Evans DJA, Signer M. 2013. Clast shape analysis and clast transport paths in glacial environments: a critical review of methods and the role of lithology. Earth-Science Reviews 121: 96-116. doi.org/10.1016/j.earscirev.2013.02.005

Matthews JA, Petch JR. 1982. Within-valley asymmetry and related problems of Neoglacial lateral moraine development at certain Jotunheimen glaciers, southern Norway. Boreas 11(3): 225-247.

Osborn G, McCarthy D, LaBrie A, Burke R. 2015. Lichenometric dating: Science or pseudo-science? Quaternary Research 83(1): 1-12.

Owen LA, Derbyshire E, Scott CH. 2003. Contemporary sediment production and transfer in high-altitude glaciers. Sedimentary Geology 155 (1-2): 13-36.

Paul MA, Evans HE. 1974. Observations on the internal structure and origin of some flutes in glacio-fluvial sediments, Blomstrandbreen, north-west Spitsbergen. Journal of Glaciology 13(69): 393-400.

Pepin N, Bradley RS, Diaz HF, Baraër M, Caceres EB, Forsythe N, et al.. 2015. Elevation-dependent warming in mountain regions of the world. Nature Climate Change 5(5): 424-430.

Powers MC. 1953. A new roundness scale for sedimentary particles. Journal of Sedimentary Research 23(2): 117119.

Price RJ. 1969. Moraines, sandar, kames and eskers near Breidamerkurjökull, Iceland. Transactions of the Institute of British Geographers 46: 17-43.

Price RJ. 1970. Moraines at Fjallsjökull, Iceland. Arctic and Alpine Research 2: 27-42.

Pritchard HD. 2017. Asia's glaciers are a regionally important buffer against drought. Nature, 545(7653), 169-174.

Rabatel A, Francou B, Jomelli V, Naveau Ph, Grancher D. 2008. A chronology of the Little Ice Age in the tropical Andes of Bolivia $\left(16^{\circ} \mathrm{S}\right)$ and its implications for climate reconstruction. Quaternary Research, 70, 198-212.

Rabatel A, Jomelli V, Naveau P, Francou B, Grancher D. 2005. Dating fluctuations of glaciers during the Little Ice Age in the tropical Andes: Charquini glaciers (Bolivia, 16º $\mathrm{S}$ ). Comptes-Rendus Géoscience 337 (15): 1311-1322. DOI: 10.1016/j.crte.2005.07.009.

Rabatel A, Machaca A, Francou B, Jomelli V. 2006. Glacier recession on Cerro Charquini $\left(16^{\circ} \mathrm{S}\right)$, Bolivia, since the maximum of the Little Ice Age (1 $7^{\text {th }}$ century). Journal of Glaciology 52(176): 110-118. DOI: $10.3189 / 172756506781828917$.

Rabatel A, Jomelli V, Francou B, Naveau P, Grancher D. 2008. The Little Ice Age in the tropical Andes of Bolivia $\left(16^{\circ} \mathrm{S}\right)$ and its implication for a climate reconstruction. Quaternary Research 70: 198-212. DOI: 10.1016/j.yqres.2008.02.012.

Rabatel A, Francou B, Soruco A, Gomez J, Cáceres B, Ceballos JL, ... Wagnon P. 2013. Current state of glaciers in the tropical Andes: a multi-century perspective on glacier evolution and climate change. The Cryosphere 7: 81102. DOI: $10.5194 /$ tc-7-81-2013.

Ramírez E, Francou B, Ribstein P, Descloitres M, Guérin R, Mendoza J, Gallaire R, Pouyaud B, Jordan E. 2001. Small glaciers disappearing in the tropical Andes: a case-study in Bolivia: Glaciar Chacaltaya $\left(16^{\circ} \mathrm{S}\right)$. Journal of Glaciology 47(157): 187-194. 
Rangecroft S, Harrison S, Anderson K, Magrath J, Castel AP, Pacheco P. 2014. A First Rock Glacier Inventory for the Bolivian Andes. Permafrost and Periglacial Processes 25 (4): 333-343.

Roberson S. 2008. Structural composition and sediment transfer in a composite cirque glacier: Glacier de St. Sorlin, France. Earth Surface Processes and Landforms 33(13), 1931-1947.

Schomacker A, Benediktsson İÖ, Ingólfsson Ó. 2014. The Eyjabakkajökull glacial landsystem, Iceland: Geomorphic impact of multiple surges. Geomorphology 218: 98-107. DOI: 10.1016/j.geomorph.2013.07.005.

Sicart JE, Wagnon P, Ribstein P. 2005. Atmospheric controls of the heat balance of Zongo Glacier (16 $6^{\circ}$ S, Bolivia). Journal of Geophysical Research 110, D12106. DOI: 10.1029/2004JD005732, 2005

Small RJ. 1983. Lateral moraines of Glacier de Tsidjiore Nouve: form, development, and implications. Journal of Glaciology 29(102): 250-259.

Smith CA, Lowell TV, Caffee MW. 2009. Lateglacial and Holocene cosmogenic surface exposure age glacial chronology and geomorphological evidence for the presence of cold-based glaciers at Nevado Sajama, Bolivia. Journal of Quaternary Science 24: 360-372.

Solomina ON, Bradley RS, Hodgson DA, Ivy-Ochs S, Jomelli V, Mackintosh AN, Young NE. 2015. Holocene glacier fluctuations. Quaternary Science Reviews 111: 9-34.

Soruco A, Vincent C, Francou B, Gonzalez JF. 2009. Glacier decline between 1963 and 2006 in the Cordillera Real, Bolivia. Geophysical Research Letters 36: L03502. DOI: 10.1029/2008GL036238.

Stokes CR, Clark CD. 1999. Geomorphological criteria for identifying Pleistocene ice streams. Annals of Glaciology 28(1): 67-74.

Tennant C, Menounos B, Wheate R, Clague JJ. 2012. Area change of glaciers in the Canadian Rocky Mountains, 1919 to 2006 . The Cryosphere 6: 1541-1552.

Thompson LG, Brecher HH, Mosley-Thompson E, Hardy DR, Mark BG. 2009. Glacier loss on Kilimanjaro continues unabated. Proceedings of the National Academy of Sciences 106(47): 19770-19775.

Wagnon P, Ribstein P, Francou B, Sicart JE. 2001. Anomalous heat and mass budget of Glaciar Zongo, Bolivia, during the 1997/98 El Niño year. Journal of Glaciology 47(156): 21-28.

WGMS. 2016. Fluctuations of Glaciers Database. World Glacier Monitoring Service, Zurich, Switzerland. DOI: 10.5904/wgms-fog-2016-08.

Wyshnytzky CE. 2017. On the mechanisms of minor moraine formation in high-mountain environments of the European Alps. PhD thesis, Queen Mary University of London, $329 \mathrm{pp}$. Available at: https://qmro.qmul.ac.uk/xmlui/handle/123456789/25992

Zemp M, Frey H, Gärtner-Roer I, Nussbaumer SU, Hoelzle M, Paul F, Haeberli W, Denzinger F, Ahlstroem AP, Anderson B, Bajracharya S, Baroni C, Braun LN, Cáceres BE, Casassa G, Cobos G, Davila LR, Delgado Granados H, Demuth M N, Espizua L, Fischer A, Fujita K, Gadek B, Ghazanfar A, Hagen JO, Holmlund P, Karimi N, Li Z, Pelto M, Pitte P, Popovnin VV, Portocarrero CA, Prinz R, Sangewar CV, Severskiy I, Sigurdsson O, Soruco A, Usubaliev R, Vincent C. 2015. Historically unprecedented global glacier decline in the early 21 st century. Journal of Glaciology 61(228): 745-762. 